Original Article

\title{
AMELIORATIVE ROLE OF SILYMARIN AGAINST ASPARTAME-INDUCED BIOCHEMICAL CHANGES, OXIDATIVE STRESS, INFLAMMATORY EFFECT AND GENOTOXICITY IN MALE ALBINO RATS
}

\author{
SABHA E. ELBALLAT ${ }^{1}$, AL-SHIMAA M. ABAS ${ }^{2}$ \\ ${ }^{1}$ Zoology Department, Faculty of Science, Zagazig University, Egypt, ${ }^{2 B i o c h e m i s t r y ~ D i v i s i o n, ~ C h e m i s t r y ~ D e p a r t m e n t, ~ F a c u l t y ~ o f ~ S c i e n c e, ~}$ \\ Zagazig University, Egypt \\ Email: dr_shmma@yahoo.com
}

Received: 11 Sep 2019, Revised and Accepted: 25 Nov 2019

\begin{abstract}
Objective: Aspartame (ASP) is one of the most common artificial sweeteners. It has been recorded to be safe by World Health Organization. However, numerous publications have concluded that ASP is a genotoxic and carcinogenic sweetener.

Methods: The current study aims to examine the effect of ASP consumption (250 mg/kg body weight/day for 90 d) on some biochemical parameters, oxidative/antioxidative status in different tissues, Tumor Necrosis Factor- $\alpha$ (TNF- $\alpha$ ), chromosomal aberration (CA) frequency and mitotic index (MI) percentage in addition to the possible ameliorative role of silymarin (50 mg/kg body weight/day for $90 \mathrm{~d})$ against ASP-induced toxicity in male albino rats.

Results: The present results have confirmed that ASP is able to induce significant increase in the blood glucose level, liver, kidney and lipid function tests, Malondialdehyde (MDA) level, serum TNF- $\alpha$ level, frequency of CA and MI\%. Meanwhile, Glutathione reduced level (GSH), Glutathione-Stransferase (GST) and catalase activity (CAT) were decreased by ASPadministration. Recovery group showed slight enhancement in all parameters but remained significant as compared to the control group. Co-administration of ASP with silymarin showed greater improvement than the recovery group.
\end{abstract}

Conclusion: Silymarin have an ameliorative role against biochemical oxidative stress, inflammatory changes in blood and different tissues, chromosomal aberrations and MI\% induced by ASP administration.

Keywords: Aspartame, Silymarin, Inflammatory marker, Oxidative/anti-oxidative status, Chromosomal aberrations

(C) 2020 The Authors. Published by Innovare Academic Sciences Pvt Ltd. This is an open access article under the CC BY license (http://creativecommons.org/licenses/by/4.0/) DOI: http://dx.doi.org/10.22159/ijcpr.2020v12i1.36831. Journal homepage: https://innovareacademics.in/journals/index.php/ijcpr

\section{INTRODUCTION}

Aspartame (Laspartyl-L-phenylalanine methyl ester) is considered as non-nutritive and non-caloric artificial sweetener consumed by more than two hundred million people worldwide. It was used in nearly 6 thousands nourishment items, including dry refreshment, breakfast grains, biting gum, refrigerated and nonrefrigerated drinks, yogurt items and pharmaceuticals [1].

ASP is quickly metabolized into 3 segments, $50 \%$ phenylalanine, $10 \%$ methanol and $40 \%$ aspartate [2]. At the point, when aspartame is absorbed by the body, aspartic acid is changed over into alanine and oxaloacetate [3]. Phenylalanine is converted into tyrosine, phenylethylamine and phenylpyruvate to a lesser degree [4]. Methanol is changed over into formaldehyde and afterward changed over to formate. These procedures are joined by the development of superoxide anion and hydrogen peroxide [5]. Formic acid is the real metabolite known for its destructive impacts of acute toxicity in humans and animals [6].

ASP is a multipotential cancer-causing operator and builds the danger of having various sorts of tumors [7]. Likewise, there was a relationship between aspartame dosing and the danger of having type 2 diabetes [8], preterm delivery [9], nephrotoxicity [10], liver toxicity [11] and histopathological effects in the parotid salivary glands [12]. ASP caused genotoxicity; it significantly induced DNA fragmentation in bone marrow cells and liver of albino rat's mothers and their offspring compared with the control animals [13].

Silymarin is a polyphenolic compound obtained from the seeds and fruits of Silybummarianum. This plant is an ancient medicinal plant used for liver, gallbladder disorders and hepatoprotection management [14]. Silymarin, the unrefined business result of milkthistle[15], is a complex of 7 flavonolignans (the most significant being silybin, isosilybin, silydianin, and silychristin) and one flavonoid (taxifolin); half of $80 \%$ of the extract concentrate. Silymarin is utilized as a correlative prescription elective throughout the world [16]. It fills in as a cancer prevention agent by searching for free-radicals and expanding glutathione concentration [17].

Thus, the present study aimed to evaluate the toxicity of ASP in addition to the possible ameliorative role of silymarin using CA assay and measurements of MI\%, blood glucose level, liver, kidney, cardiac function tests, MDA level and serum TNF- $\alpha$ level, GSH level, GST and catalase activity in male albino rats.

\section{MATERIALS AND METHODS}

\section{Chemicals}

Aspartame (ASP) was acquired from Al-Ameriyapharma company, Egypt, as tablets; every tablet contains $20 \mathrm{mg}$ of aspartame. Silymarin was purchased from the pharmacy (Legalon ${ }^{\circledR} 140 \mathrm{mg}$ each capsule contains $140 \mathrm{mg}$ Silymarin). Doses of aspartame or silymarin were determined by dissolving estimated amounts in refined water, and they were managed at a volume of $10 \mathrm{ml} / \mathrm{kg}$.

\section{Experimental design}

The present work was done using 50 adult male albino rats (190$200 \mathrm{gm}$ weight). The animals were kept up under standard research facility conditions with water and nourishment. The investigation was approved as recommended in the guidelines given by the Ethical Review Committee of Zagazig University, Egypt. The rats were divided into five equal groups. Group I (Control): received ordinary diet and water. Group 2 (silymarin): animals were orally administrated with a dose of silymarin $(50 \mathrm{mg} / \mathrm{kg} /$ day) for $90 \mathrm{~d}$. This dose was based on experiments assessing that LD50 was 385 $\mathrm{mg} / \mathrm{kg}$ in rats [18]. Group 3 (Aspartame): received ASP by gastric tube $(250 \mathrm{mg} / \mathrm{kg} / \mathrm{d})$ [19] for $90 \mathrm{~d}$. This dose was compared to the satisfactory every day admission in people (defined by the WHO) of 
40-50 mg/kg/d. Species correction required a five to six times higher dose in rats than in humans, as rats metabolize aspartame faster than humans [20]. Group 4 (Recovery Group) administrated aspartame as in Group 3, but animals were left for two weeks after stopping ASP to recover before they were killed. Group 5 (Aspartame+silymarin) rats co-administered silymarin with ASP daily for $90 \mathrm{~d}$.

\section{Collection and sampling of blood}

At the end of the experimental period, 5 rats from each group were used for the chromosomal preparation and MI measurement from their bone marrow. The remaining 5 animals in each group had fasted for 12 hand were presented to mild anesthesia. Blood was gathered from their orbital sinus and blood serum was set up by accumulation of blood in an anticoagulant-free tube for separation of serum which was moved into another tube and kept frozen at-20 ${ }^{\circ} \mathrm{C}$ [21].

Tissue processing for oxidative parameters and histopathological examination

After blood collection, liver, kidney and heart tissues were removed, sectioned, and either homogenized with ice-cold phosphate-buffered saline ( $\mathrm{pH}$ 7.4) or processed for general histology. The homogenates were centrifuged and the resulting supernatant was moved into another tube and protected until utilized. The other parts of tissues were fixed in $10 \%$ buffered formalin for histopathological study [22].

\section{Biochemical measurements}

\section{- Blood glucose, kidney, liver and lipid functions in blood serum}

Fasting blood glucose was analyzed using colorimetric method [23], Urea [24] and creatinine concentration [25].

The biochemical parameters evaluated were liver biomarkers such as, bilirubin [26], ALT, AST [27] and ALP [28] using diagnostics kits. There were serum lipid profiles (Triglyceride and Total cholesterol) $[29,30]$

\section{- Oxidative stress marker measurements}

MDA [31], Glutathione reduced (GSH) [32], Glutathione-Stransferase (GST) [33] and Catalase (CAT) [34] were determined according to kits purchased from Biodiagnostic Company (Biodiagnostic, Egypt).

\section{- Inflammatory markers}

Rat Tumor Necrosis Factor- $\alpha$ (TNF- $\alpha$ ) was determined by ELISA according to Catalogue No. 201-11-0765 kits

\section{Chromosomal aberration assay}

Chromosomes were extracted from white blood cells in the bone marrow of rats from each group according to the method described by [35]. By Giemsa stain (1.5\%), the slides were stained for about 20 min. The slides were carefully scanned for the metaphase spreads under the $\times 10$ objective and then under $\times 40$ objective of the light microscope. The well-spread metaphases were examined under $\times 100$ (oil immersion) and the photomicrographs of the well-spread chromosomes were taken. A total of 50 well-spread metaphases from each rat were analyzed.

\section{- MI determination}

The MI was examined for each rat in all groups according to the following formula: $\mathrm{MI}=$ (Number of dividing cells/Total examined cells) $\times 100$

\section{Statistical analysis}

All outcomes were analyzed by SPSS programming (variant 14). Data were expressed as mean \pm SE. A comparison of mean values of factors among various groups was done using the ANOVA test. $\mathrm{P}<0.05$ was considered to be significant [36].

\section{RESULTS}

Effect of aspartame administration on body weight of all studied groups

Data showed that there was a significant increase in the final body weight in group 3 (aspartame) $(\mathrm{P}<0.001)$ and Group 4 (Recovery Group) $(\mathrm{P}<0.05)$ which amounted to $27.1 \%$ and $13.8 \%$ respectively. In group 5 (Aspartame+silymarin) there was a statistically non-significant increase in the final body weight, which amounted to $7 \%$ (table 1 ) and (fig. 1).

Table 1: Initial body weight and final body weight of all studied groups

\begin{tabular}{lll}
\hline Groups & Variable & Final weight (g) (mean \pm SEM) \% change \\
\cline { 2 - 3 } & Initial body weight (g) (mean \pm SEM) \% change & $342.25 \pm 15.75$ \\
\hline Group I (Control) & $150.5 \pm 3.06$ & $358.8 \pm 7.94$ \\
Group 2 (Silymarin) & $146.4 \pm 2.37$ & $4.8 \%$ \\
& $-2.7 \%$ & $435 \pm 8.94{ }^{* * *}$ \\
Group 3 (Aspartame) & $154.8 \pm 1.52$ & $27.1 \%$ \\
& $2.8 \%$ & $389.4 \pm 17.56^{*}$ \\
Group 4 (Recovery Group) & $148.6 \pm 2.67$ & $13.8 \%$ \\
Group 5 (Aspartame+silymarin) & $-1.3 \%$ & $366.40 \pm 10.27$ \\
& $146.6 \pm 3.25$ & $7 \%$ \\
\hline
\end{tabular}

Significant differences are indicated (One-way ANOVA followed by post hoc Duncan's multiple range test). ${ }^{*} \mathrm{P}<0.05$, $* * \mathrm{P}<0.01, * * * \mathrm{P}<0.001$ significantly different from control.

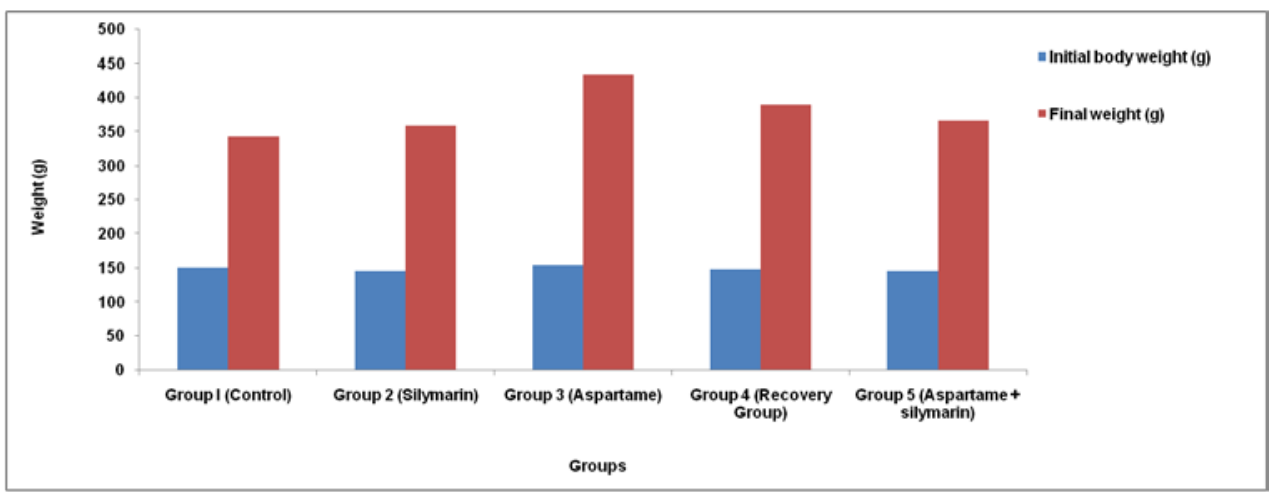

Fig. 1: Initial body weight and final body weight of all studied groups 
Effect of aspartame administration on glucose, liver, kidney and lipid function tests

Data presented in (table 2) and (fig. 2, fig. 3) showed that the mean level of glucose was increased in groups 3, 4 and 5. This increase was statistically significant in group $3(\mathrm{P}<0.01)$ and group $4(\mathrm{P}<0.05)$. In group 5 silymarin administration decreased glucose level which was statistically non-significant compared to the control group $(P>0.05)$.

Also, data showed a significant $(\mathrm{P}<0.05)$ increase in ALT activity in group 3 . This value was decreased in group 4 and $5(\mathrm{P}>0.05)$. The mean value of AST activity increased in group 3,4 and 5 but this increase was statistically non-significant $(\mathrm{P}>0.05)$ compared to control group. ASP administration caused slight decrease in the mean level of albumin (P > $0.05)$ and a slight increase in total bilirubin $(P \quad>0.05)$

Data confirmed that ASP administration caused a slight increase in urea concentration $(B$ 0.05) . ASP caused a significant $(P<0.01)$ increase in the mean level of creatinine. These values showed a slight decrease in group 4. But this was still statistically significant. Group 5 had marked decrease which was statistically non-significant $(\mathrm{P}>0.05)$ as compared to the control group.
The present result declared that the dosing of ASP caused a significant increase in the mean level of Cholesterol $(\mathrm{P}<0.01)$ and triglyceride in group $3(\mathrm{P}<0.001)$. These values showed a slight decrease in group 4 . But this was still statistically significant. Group 5 had marked decrease which was statistically non-significant $(\mathrm{P}>$ 0.05 ) as compared to the control group.

Effect of aspartame administration on oxidative and antioxidative parameters in liver tissue

Data showed that the dosing of ASP caused a marked significant increase on hepatic MDA level $(\mathrm{P}<0.001)$ and a significant decrease on GSH levels $(\mathrm{P}<0.05)$, GST and catalase activities $(\mathrm{P}<0.001)$ as compared to the control group. The elevation on MDA level showed a slight decrease in group $4(\mathrm{P}<0.01)$ and a marked decrease in group 5 but it remained significant $(\mathrm{P}<0.05)$ at the statistical level. Also, the decrease on hepatic GSH level, GST and catalase activities were enhanced in group 4 but, it was statistically significant as group 3 and showed a marked elevation in group 5 which was statistically non-significant (B 0.05) as compared to the control group (table 3).

Table 2: Effect of aspartame administration on glucose, liver, kidney and lipid function tests

\begin{tabular}{|c|c|c|c|c|c|}
\hline \multirow[t]{2}{*}{ Parameters } & \multicolumn{5}{|l|}{ Groups } \\
\hline & $\begin{array}{l}\text { Group I } \\
\text { (Control) }\end{array}$ & $\begin{array}{l}\text { Group 2 } \\
\text { (Silymarin) }\end{array}$ & $\begin{array}{l}\text { Group 3 } \\
\text { (Aspartame) }\end{array}$ & $\begin{array}{l}\text { Group } 4 \\
\text { (Recovery Group) }\end{array}$ & $\begin{array}{l}\text { Group } 5 \\
\text { (Aspartame +silymarin) }\end{array}$ \\
\hline Glucose (mg/dl) & $115.66 \pm 4.9$ & $128.75 \pm 3.9$ & $151 \pm 10.1^{* *}$ & $141 \pm 5.5^{*}$ & $125.7 \pm 4.14$ \\
\hline $\operatorname{ALT}(\mathrm{U} / \mathrm{l})$ & $41.7 \pm 1.1$ & $40.36 \pm 0.73$ & $46.17 \pm 2.09^{*}$ & $43.08 \pm 0.46$ & $40.92 \pm 0.96$ \\
\hline AST (U/l) & $198.7 \pm 6.93$ & $210.8 \pm 9.16$ & $228.77 \pm 4.14$ & $223 \pm 10.7$ & $209.8 \pm 5.65$ \\
\hline ALB $(\mathrm{g} / \mathrm{dl})$ & $3.22 \pm 0.07$ & $3.14 \pm 0.06$ & $3.17 \pm 0.06$ & $3.20 \pm .16$ & $3.14 \pm 0.09$ \\
\hline T. bilirubin $(\mathrm{mg} / \mathrm{dl})$ & $0.43 \pm 0.06$ & $0.45 \pm 0.02$ & $0.52 \pm 0.02$ & $0.50 \pm 0.03$ & $0.41 \pm 0.02$ \\
\hline Urea $(\mathrm{mg} / \mathrm{dl})$ & $29.5 \pm 1.84$ & $29 \pm 2.2$ & $32 \pm 0.7$ & $31.2 \pm 1.56$ & $30.1 \pm 1.7$ \\
\hline Creatinine (mg/dl) & $0.56 \pm 0.03$ & $0.57 \pm 0.02$ & $0.80 \pm 0.04^{* *}$ & $0.71 \pm 0.03^{*}$ & $0.58 \pm 0.04$ \\
\hline Cholesterol (mg/dl) & $111.5 \pm 2.0$ & $109.8 \pm 1.8$ & $127.2 \pm 2.4^{* *}$ & $125.4 \pm 2.7^{* *}$ & $117.7 \pm 2.3$ \\
\hline Triglyceride $(\mathrm{mg} / \mathrm{dl})$ & $88.7 \pm 6.7$ & $86.0 \pm 2.2$ & $154.2 \pm 5.2^{* * *}$ & $135.2 \pm 5.08^{* * *}$ & $98.1 \pm 6.4$ \\
\hline
\end{tabular}

Values are expressed as the means \pm SEM, Significant differences are indicated (One-way ANOVA followed by post hoc Duncan's multiple range test), ${ }^{*} \mathrm{P}<0.05,{ }^{* *} \mathrm{P}<0.01,{ }^{* * *} \mathrm{P}<0.001$ significantly different from control.

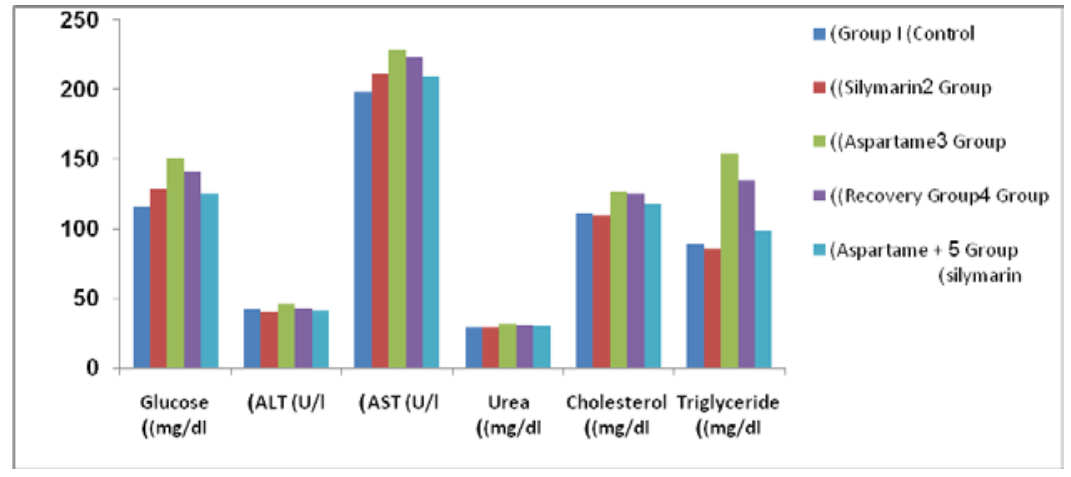

Fig. 2: Effect of aspartame administration on glucose, ALT, AST, urea, cholesterol and triglyceride

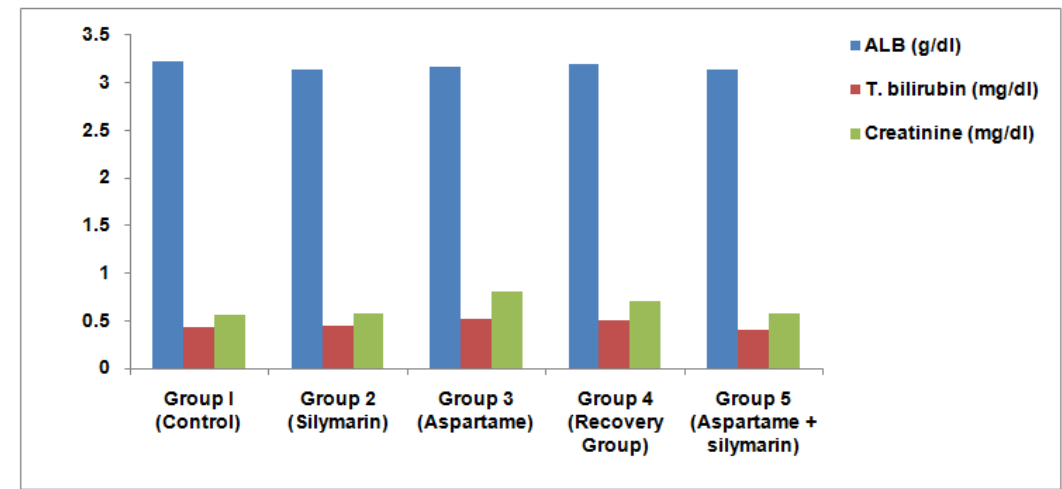

Fig. 3: Effect of aspartame administration on albumin, total bilirubin and creatinine 
Table 3: Effect of aspartame administration on oxidative and anti-oxidative parameters in liver tissue

\begin{tabular}{|c|c|c|c|c|}
\hline \multirow[t]{2}{*}{ Groups } & \multicolumn{4}{|l|}{ Liver tissue } \\
\hline & MDA (nmol/g) & GST (U/g) & GSH (mmol/g) & CAT (U/g) \\
\hline Group I (Control) & $31.8 \pm 0.79$ & $427.7 \pm 29.8$ & $2.26 \pm 0.22$ & $193.4 \pm 2.5$ \\
\hline \multirow{2}{*}{ Group 2 (Silymarin) } & $36.4 \pm 2.3$ & $412.5 \pm 43.3$ & $2.20 \pm 0.18$ & $197.8 \pm 0.8$ \\
\hline & $14.4 \%$ & $-3.5 \%$ & $-2.7 \%$ & $2.3 \%$ \\
\hline \multirow[t]{2}{*}{ Group 3 (Aspartame) } & $84.4 \pm 1.4^{* * *}$ & $144.4 \pm 13.3^{* * *}$ & $0.80 \pm 0.06^{*}$ & $183.15 \pm 0.94^{* * *}$ \\
\hline & $156.4 \%$ & $-66.2 \%$ & $-64.6 \%$ & $-5.3 \%$ \\
\hline \multirow[t]{2}{*}{ Group 4 (Recovery Group) } & $65.9 \pm 3.6^{* *}$ & $157.8 \pm 30.8^{* * *}$ & $1.02 \pm 0.17^{*}$ & $187.3 \pm 1.4^{* *}$ \\
\hline & $107.2 \%$ & $-63.1 \%$ & $-54.9 \%$ & $-3.2 \%$ \\
\hline \multirow[t]{3}{*}{ Group 5 (Aspartame+silymarin) } & $40.09 \pm 1.9^{*}$ & $400.9 \pm 20.2$ & $1.28 \pm 0.24$ & $192.9 \pm 0.68$ \\
\hline & $26.1 \%$ & $-6.2 \%$ & $-43.4 \%$ & $-0.3 \%$ \\
\hline & $\mathrm{P}<0.001$ & $\mathrm{P}<0.001$ & $P=0.001$ & $\mathrm{P}<0.001$ \\
\hline
\end{tabular}

Values are expressed as the means \pm SEM, \% change. Significant differences are indicated (One-way ANOVA followed by post hoc Duncan’s multiple range test). ${ }^{*} \mathrm{P}<0.05,{ }^{* *} \mathrm{P}<0.01,{ }^{* * *} \mathrm{P}<0.001$ significantly different from control.

Effect of aspartame administration on oxidative and
antioxidative parameters in kidney tissue

Results confirmed that ASP administration caused a highly significant elevation in kidney MDA level $(\mathrm{P}<0.01)$ and a significant decrease in GSH levels $(\mathrm{P}<0.01)$, GST and catalase activities $(\mathrm{P}<0.001)$ as compared to the control group. The elevation in MDA level showed slight decrease in group $4(\mathrm{P}<0.01)$ and a marked decrease in group 5 but, it was still significant $(\mathrm{P}<0.05)$ at the statistical level. The decreased kidney GSH level, GST and catalase activities were enhanced in group 4, but the values were remained statistically significant as group 3 and showed marked elevation in group 5 which was statistically non-significant $(\mathrm{P}>$ $0.05)$ in case of GSH and catalase and significant $(\mathrm{P}<0.05)$ in MDA and GST as compared to control group (table 4).

Table 4: Effect of aspartame administration on oxidative and antioxidative parameters in kidney tissue

\begin{tabular}{|c|c|c|c|c|}
\hline \multirow[t]{2}{*}{ Groups } & \multicolumn{4}{|l|}{ Kidney tissue } \\
\hline & MDA (nmol/g) & GST (U/g) & GSH (mmol/g) & CAT (U/g) \\
\hline Group I (Control) & $58.1 \pm 3.5$ & $369.06 \pm 9.4$ & $3.12 \pm 0.08$ & $197.7 \pm 0.08$ \\
\hline \multirow[t]{2}{*}{ Group 2 (Silymarin) } & $53.5 \pm 0.97$ & $370.4 \pm 2.0$ & $3.35 \pm 0.12$ & $198.5 \pm 0.40$ \\
\hline & $-7.9 \%$ & $0.4 \%$ & $7.4 \%$ & $0.4 \%$ \\
\hline \multirow[t]{2}{*}{ Group 3 (Aspartame) } & $107.3 \pm 6.1^{* *}$ & $305.5 \pm 1.4^{* * *}$ & $1.95 \pm .0 .27^{* *}$ & $191.9 \pm 1.0^{* * *}$ \\
\hline & $84.6 \%$ & $-17.2 \%$ & $-37.5 \%$ & $-2.9 \%$ \\
\hline \multirow[t]{2}{*}{ Group 4 (Recovery Group) } & $93.6 \pm 3.1^{* *}$ & $338.6 \pm 6.4^{* *}$ & $2.03 \pm 0.36^{* *}$ & $192.6 \pm 0.26^{* * *}$ \\
\hline & $61.1 \%$ & $-8.3 \%$ & $-34.9 \%$ & $-2.6 \%$ \\
\hline \multirow[t]{3}{*}{ Group 5 (Aspartame+silymarin) } & $78.2 \pm 1.08^{*}$ & $341.3 \pm 7.6^{*}$ & $2.61 \pm 0.04$ & $197.2 \pm 0.71$ \\
\hline & $34.6 \%$ & $-7.5 \%$ & $-16.3 \%$ & $-0.3 \%$ \\
\hline & $\mathrm{P}<0.001$ & $\mathrm{P}<0.001$ & $\mathrm{P}<0.001$ & $\mathrm{P}<0.001$ \\
\hline
\end{tabular}

Values are expressed as the means \pm SEM, \% change, Significant differences are indicated (One-way ANOVA followed by post hoc Duncan's multiple range tests) $* \mathrm{P}<0.05,{ }^{* *} \mathrm{P}<0.01,{ }^{* * *} \mathrm{P}<0.001$ significantly different from control.

Effect of aspartame administration on oxidative and antioxidative parameters in heart tissue

The present study recorded that ASP administration caused a highly significant elevation in cardiac MDA level $(\mathrm{P}<0.001)$ and a significant decrease in GSH levels $(\mathrm{P}<0.01)$, GST and catalase activities $(\mathrm{P}<0.001)$ as compared to control values. The elevation in MDA level showed a slight decrease in group $4(\mathrm{P}<0.05)$ and marked decrease in group 5 which was statistically non-significant $(\mathrm{P}>0.05)$. The decreased cardiac GSH level, GST and catalase activities were enhanced in group 4 but still statistically significant as group 3 and showed a marked elevation in group 5 which was statistically non-significant (B 0.05 ) as compared to control group (table 5).

Data showed that ASP has an effect on the different tissues. Recovery period (14 d) was not enough to restore the oxidative and antioxidative parameters to its normal levels. Also, co-administration of ASP with silymarin showed great improvement than the recovery group (fig. 4, fig. 5, fig. 6, fig. 7).

Table 5: Effect of aspartame administration on oxidative and antioxidative parameters in heart tissue

\begin{tabular}{|c|c|c|c|c|}
\hline \multirow[t]{2}{*}{ Groups } & \multicolumn{4}{|l|}{ Heart tissue } \\
\hline & MDA (nmol/g) & GST (U/g) & GSH (mmol/g) & CAT (U/g) \\
\hline Group I (Control) & $20.1 \pm 0.26$ & $198.4 \pm 14.4$ & $2.66 \pm 0.05$ & $188.8 \pm 5.3$ \\
\hline \multirow[t]{2}{*}{ Group 2 (Silymarin) } & $18.36 \pm 1.74$ & $208.5 \pm 10.7$ & $2.80 \pm 0.03$ & $190.7 \pm 4.6$ \\
\hline & $-0.9 \%$ & $5.1 \%$ & $5.3 \%$ & $1 \%$ \\
\hline \multirow[t]{2}{*}{ Group 3 (Aspartame) } & $28.53 \pm 0.19^{* * *}$ & $128.3 \pm 9.93^{* * *}$ & $2.22 \pm 0.15^{* *}$ & $154.3 \pm 2.4^{* * *}$ \\
\hline & $41.9 \%$ & $-35.3 \%$ & $-16.5 \%$ & $-18.27 \%$ \\
\hline \multirow[t]{2}{*}{ Group 4 (Recovery Group) } & $27.32 \pm 1.10^{*}$ & $162.12 \pm 4.7^{*}$ & $2.39 \pm 0.05^{*}$ & $162.9 \pm 2.1^{* *}$ \\
\hline & $35.8 \%$ & $-18.2 \%$ & $-10.2 \%$ & $-13.7 \%$ \\
\hline \multirow[t]{3}{*}{ Group 5 (Aspartame+silymarin) } & $21.1 \pm 0.35$ & $184.3 \pm 9.3$ & $2.63 \pm 0.02$ & $181.1 \pm 5.2$ \\
\hline & $5 \%$ & $-7.1 \%$ & $-1.1 \%$ & $-4.1 \%$ \\
\hline & $P<0.001$ & $P<0.001$ & $P<0.001$ & $P<0.001$ \\
\hline
\end{tabular}

Values are expressed as the means \pm SEM, \% change, Significant differences are indicated (One-way ANOVA followed by post hoc Duncan's multiple range test), $* \mathrm{P}<0.05,{ }^{* *} \mathrm{P}<0.01,{ }^{* * *} \mathrm{P}<0.001$ significantly different from control. 


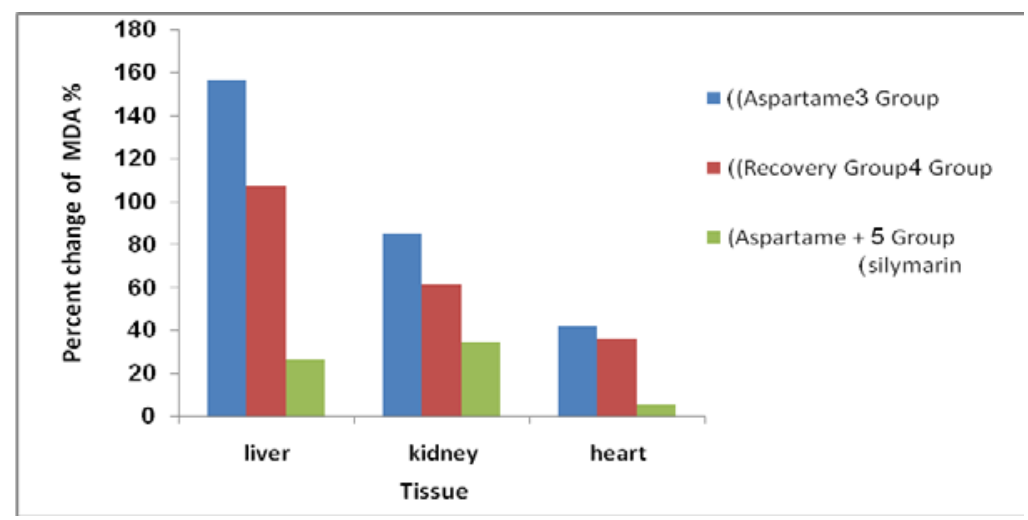

Fig. 4: Effect of aspartame administration on percent change of MDA in aspartame, recovery and aspartame+silymarin groups in compared to the control group in different tissues

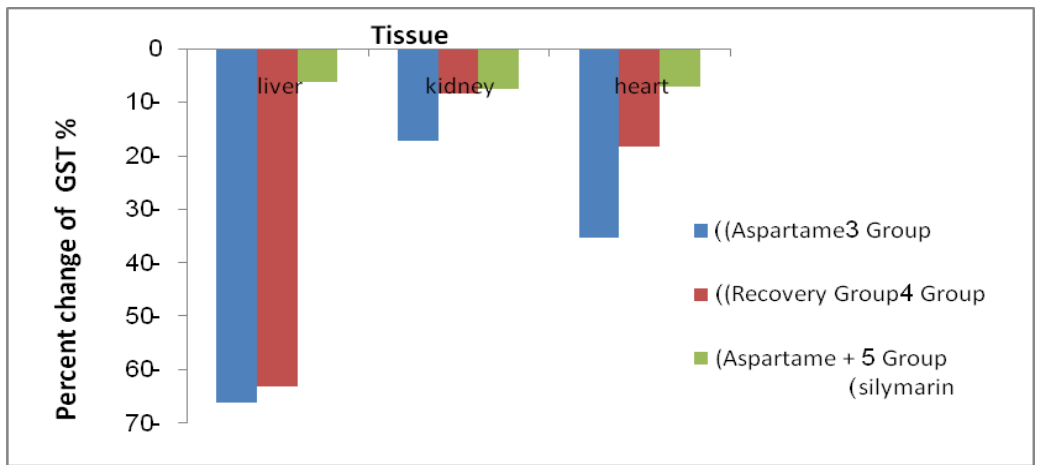

Fig. 5: Effect of aspartame administration on percent change of GST in aspartame, recovery and aspartame+silymarin groups in compared to the control group in different tissues

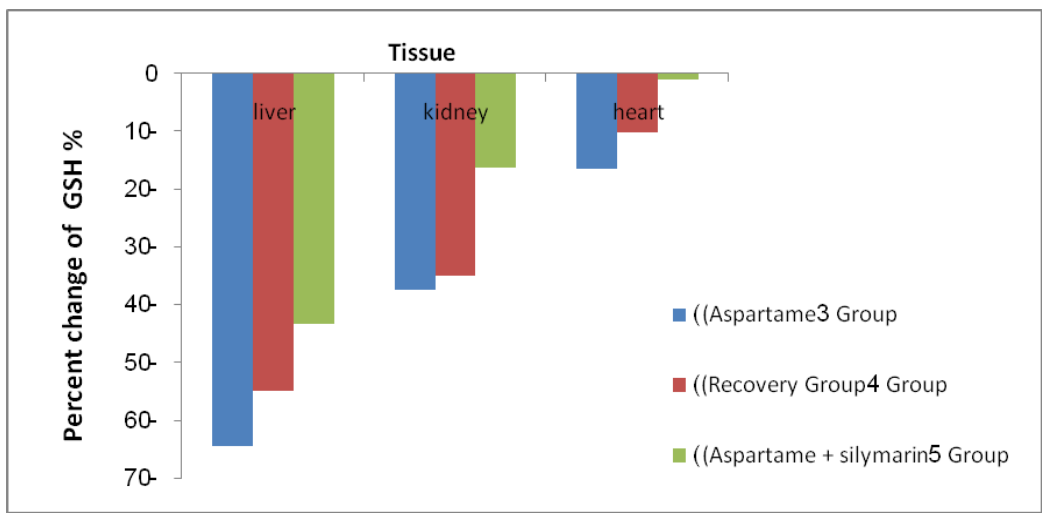

Fig. 6: Effect of aspartame administration on percent change of GSH in aspartame, recovery and aspartame+silymarin groups in compared to the control group in different tissues

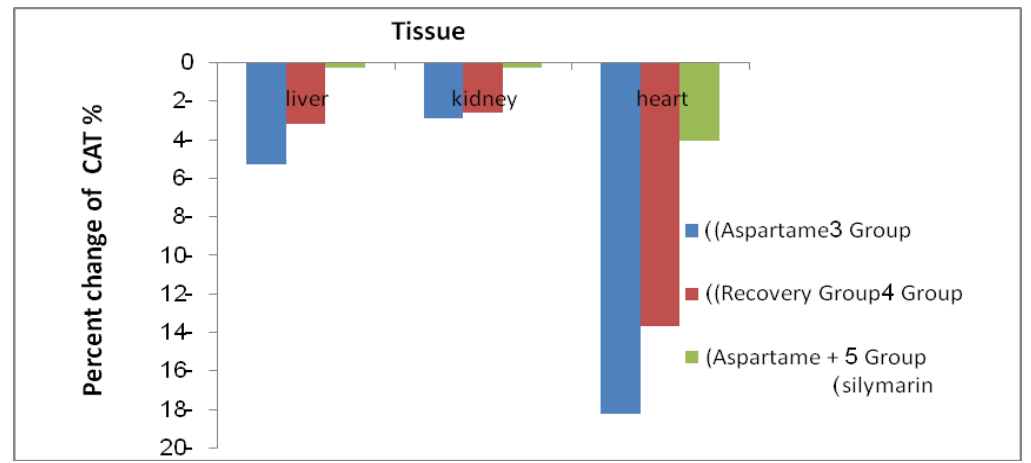

Fig. 7: Effect of aspartame administration on percent change of CAT in aspartame, recovery and aspartame+silymarin groups in compared to the control group in different tissues 
Table 6: Effect of aspartame administration on serum levels of TNF-- $\alpha$ in all studied groups

\begin{tabular}{ll}
\hline Groups & TNF- $\boldsymbol{\alpha}(\mathbf{n g} / \mathbf{l})$ \\
\hline Group I (Control) & $96.8 \pm 2.3$ \\
Group 2 (Silymarin) & $96.6 \pm 1.1-0.21 \%$ \\
Group 3 (Aspartame & $129.6 \pm 2.8^{* * *} 33.9 \%$ \\
Group 4 (Recovery Group) & $113.8 \pm 4.4^{* *} 17.6 \%$ \\
Group 5 (Aspartame+silymarin) & $102.7 \pm 2.86 .1 \%$ \\
P value & $\mathrm{P}<0.001$ \\
\hline
\end{tabular}

Values are expressed as the means \pm SEM, \% change. Significant differences are indicated (One-way ANOVA followed by post hoc Duncan's multiple range test), ${ }^{*} \mathrm{P}<0.05,{ }^{* *} \mathrm{P}<0.01,{ }^{* * *} \mathrm{P}<0.001$ significantly different from control.

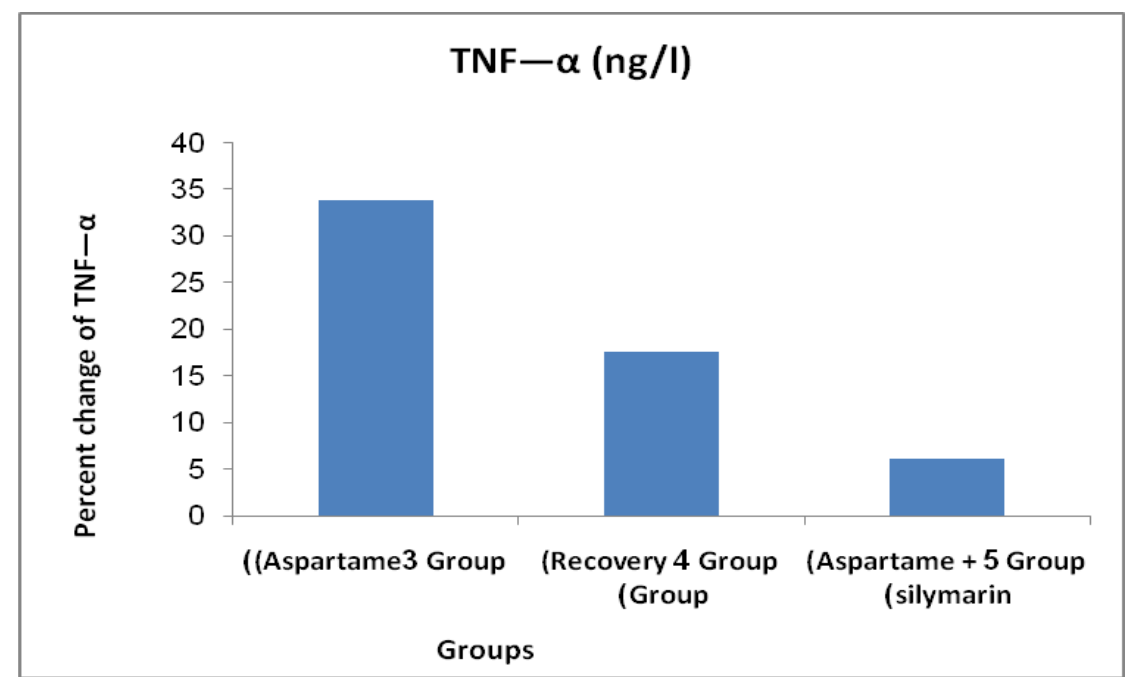

Fig. 8: Effect of aspartame administration on percent change of $\mathrm{TNF}-\alpha$ in aspartame, recovery and aspartame+silymarin groups in compared to the control group in different tissues

\section{Effect of aspartame administration on serum levels of TNF-- $\alpha$ in all studied groups}

Results indicated that there was a highly significant increase in the mean level of serum TNF- $\alpha$ in group $3(\mathrm{P}<0.001)$ as compared to the control group. Group 4 showed a significant increase $(\mathrm{P}<0.05)$ but less than that of group 3. In group 5, there was a statistically nonsignificant increase (table 6) (fig. 8).

\section{The effect on the chromosomal aberration frequency}

Under the conditions of the present investigation, the control rats recorded chromosomal aberration (CA) frequency within the normal values while oral administration of ASP to male rats induced significant $(\mathrm{p}<0.001)$ increase in the percentage of total chromosomal aberration (TCA) reaching $63.00 \pm 2.89$ as compared with $15.60 \pm 0.67$ in control group. TCA included the total numerical aberration (TNA) and the total structural aberration TSA (table 7) (fig. 9).

The numerical aberrations were mainly the aneuploidy (hyperdiploid) and polyploidy (table 7), (fig. 9, fig. 10). Meanwhile, the deletions, dicentric chromosomes, exchange fig. and breaks were the most abundant structural aberrations (table 7), (fig. 9, fig. 11); all of these aberrations significantly $(p<0.001)$ increased as compared with control values.

In the present study, when rats were orally administered with ASP then left for two weeks post-treatment to recover (recovery group), the frequency of TCA (TNA and TSA) was clearly reduced as compared with ASP group. Hyperdiploid and polyploidy were decreased but their values remained significant $(\mathrm{p}<0.01)$ as compared with control (table 7), (fig. 9). Except for exchange figures, all types of structural aberrations decreased and became non-significant at the statistical level. Thus, better CA improvement after stoppage of ASP may require an extension of the recovery period to more than two weeks.

According to the result of the present study, silymarin treated rats showed a significant $(\mathrm{p}<0.05)$ decrease in the frequency of TNA as compared with the control value. Herein, aneuploidy (hyperdploid) was significantly $(\mathrm{p}<0.05)$ decreased and all other types of CA were non-significantly changed. This confirmed that silymarin itself does not induce CA and is able to repair the chromosomal damage (table 7), (fig. 9).

Moreover, the present data revealed that silymarin drug as antioxidant alleviated the genotoxicity of ASP by clear reduction in the frequency of TCA (TNA and TSA) in bone marrow cells of rats coadministered both ASP plus silymarin. All types of CA (hyperdiploid, polydiploidy, deletions, dicentic chromosomes and breaks) were highly reduced and became non-significant as compared with control values. However, the frequency of TCA (TNA and TSA mainly exchange figures) remained significant as compared with control values (table 7), (fig. 9). The ameliorative role of silymarin against ASP toxicity might be a result of its anti-oxidative activity; it acts as a scavenging agent against the free-radicals induced by ASP that were the main cause of ASP genotoxicity repairing the chromosomal damage in bone marrow cells of ASP treated rats.

\section{The effect on the percentage of the mitotic index}

According to the present work, the percentage of MI was increased in ASP group as compared with a control value (table 7), (fig. 12). Increased MI rate might result from a high progression rate of cells from the stage of DNA synthesis (S-phase) to mitosis (M-phase) of the cell cycle. This indicates the potential of ASP to induce more cells to divide and hence inducing cancer cells.

The present data recorded that the value of MI was relatively decreased in the recovery group as compared with the aspartame group (table 7), (fig. 12). Rats had been left for $14 \mathrm{~d}$ post-treatment with ASP to recover and this period was not enough to reach a complete recovery.

In addition, data showed that there was no significant change in $\mathrm{MI} \%$ in silymarin treated rats. The animals administered with both ASP plus silymarin recorded an improvement in MI\% as compared with rats treated with ASP alone, but the value didn't reach the control level (table 7), (fig. 12). 
Table 7: The frequencies of chromosomal aberrations (numerical and structural) and MI\% in bone marrow cells of male albino rats after ASP and/or silymarin administration

\begin{tabular}{|c|c|c|c|c|c|c|c|c|c|c|c|c|c|}
\hline \multirow[t]{3}{*}{ Groups } & \multirow{3}{*}{$\begin{array}{l}\text { No. } \\
\text { of } \\
\text { rat } \\
\text { s }\end{array}$} & \multirow{3}{*}{$\begin{array}{l}\text { No. of } \\
\text { scored } \\
\text { cells } \\
50 / \text { rat }\end{array}$} & \multicolumn{8}{|c|}{ Chromosomal aberrations } & & \multicolumn{2}{|c|}{$\begin{array}{l}\text { Mitotic } \\
\text { index }\end{array}$} \\
\hline & & & \multicolumn{3}{|c|}{ Numerical aberrations } & \multicolumn{5}{|c|}{ Structural aberrations } & \multirow[t]{2}{*}{ TCA } & \multirow[b]{2}{*}{$\%$} & \multirow{2}{*}{$\begin{array}{l}\text { Metap } \\
\text { hases } \\
/ 1000 \\
\text { cell }\end{array}$} \\
\hline & & & $\begin{array}{l}\text { Aneupl } \\
\text { oidy } \\
\text { (hyper } \\
\text { diploid) }\end{array}$ & $\begin{array}{l}\text { Polyplo } \\
\text { idy }\end{array}$ & TNA & $\begin{array}{l}\text { Deleti } \\
\text { on }\end{array}$ & Dicentric & $\begin{array}{l}\text { Excha } \\
\text { nge }\end{array}$ & Break & TSA & & & \\
\hline Control & 5 & 250 & $\begin{array}{l}9.00 \\
\pm 0.00\end{array}$ & $\begin{array}{l}1.00 \pm \\
0.31\end{array}$ & $\begin{array}{l}12.2 \pm 0 \\
.48\end{array}$ & $\begin{array}{l}0.40 \pm 0 \\
.24\end{array}$ & $\begin{array}{l}1.20 \pm 0.2 \\
0\end{array}$ & $\begin{array}{l}0.40 \pm 0 \\
.24\end{array}$ & $\begin{array}{l}0.20 \pm 0 \\
.20\end{array}$ & $\begin{array}{l}3.40 \pm 0 . \\
24\end{array}$ & $\begin{array}{l}15.60 \pm \\
0.67\end{array}$ & 1 & 10 \\
\hline Silymarin & 5 & 250 & $\begin{array}{l}4.60 \pm 1 . \\
02^{* \downarrow}\end{array}$ & $\begin{array}{l}2.40 \pm \\
0.50\end{array}$ & $\begin{array}{l}9.2 \pm 0 . \\
37^{*} \downarrow\end{array}$ & $\begin{array}{l}1.00 \pm 0 \\
.00\end{array}$ & $\begin{array}{l}0.20 \pm 0.2 \\
0\end{array}$ & $\begin{array}{l}1.40 \pm 0 \\
.24\end{array}$ & $\begin{array}{l}0.60 \pm 0 \\
.40\end{array}$ & $\begin{array}{l}4.00 \pm 0 . \\
70\end{array}$ & $\begin{array}{l}13.20 \pm \\
0.73\end{array}$ & $\begin{array}{l}1 . \\
2\end{array}$ & 12 \\
\hline Aspartame & 5 & 250 & $\begin{array}{l}14.00 \pm \\
0.94^{* * *}\end{array}$ & $\begin{array}{l}14.00 \pm \\
0.83^{* * *}\end{array}$ & $\begin{array}{l}35.40 \pm \\
1.86^{* * *}\end{array}$ & $\begin{array}{l}5.40 \pm 0 \\
.50^{* * *}\end{array}$ & $\begin{array}{l}5.40 \pm 0.6 \\
7^{* * *}\end{array}$ & $\begin{array}{l}6.00 \pm 0 \\
.00 * * *\end{array}$ & $\begin{array}{l}3.00 \pm 0 \\
.31^{* * *}\end{array}$ & $\begin{array}{l}27.60 \pm \\
1.43^{* * *}\end{array}$ & $\begin{array}{l}63.00 \pm \\
2.89 * * *\end{array}$ & 5 & 50 \\
\hline $\begin{array}{l}\text { Aspartame } \\
\text { recovery }\end{array}$ & 5 & 250 & $\begin{array}{l}13.20 \pm \\
1.11^{* *}\end{array}$ & $\begin{array}{l}4.20 \pm 1 . \\
42^{* *}\end{array}$ & $\begin{array}{l}18.40 \pm \\
0.40^{* * *}\end{array}$ & $\begin{array}{l}0.20 \pm 0 \\
.20\end{array}$ & $\begin{array}{l}1.20 \pm 0.2 \\
0\end{array}$ & $\begin{array}{l}4.00 \pm 0 \\
.31^{* * *}\end{array}$ & $\begin{array}{l}0.40 \pm 0 \\
.24\end{array}$ & $\begin{array}{l}6.80 \pm 0 . \\
20 * * *\end{array}$ & $\begin{array}{l}25.20 \pm \\
0.48^{* * *}\end{array}$ & $\begin{array}{l}4 . \\
4\end{array}$ & 44 \\
\hline $\begin{array}{l}\text { Aspartame+s } \\
\text { ilymarin }\end{array}$ & 5 & 250 & $\begin{array}{l}11.00 \pm \\
0.31\end{array}$ & $\begin{array}{l}3.00 \pm \\
0.94\end{array}$ & $\begin{array}{l}16.20 \pm \\
0.20^{* *}\end{array}$ & $\begin{array}{l}1.20 \pm 0 \\
.48\end{array}$ & $\begin{array}{l}1.20 \pm 0.2 \\
0\end{array}$ & $\begin{array}{l}4.00 \pm 0 \\
.00 * * *\end{array}$ & $\begin{array}{l}0.60 \pm 0 \\
.24\end{array}$ & $\begin{array}{l}4.80 \pm 0 . \\
24 * * *\end{array}$ & $\begin{array}{l}24.60 \pm \\
0.40^{* * *}\end{array}$ & $\begin{array}{l}3 . \\
9\end{array}$ & 39 \\
\hline
\end{tabular}

Values are expressed as the means \pm SEM, Significant differences are indicated $* \mathrm{P}<0.05,{ }^{* *} \mathrm{P}<0.01,{ }^{* * *} \mathrm{P}<0.001$ significantly different from control.

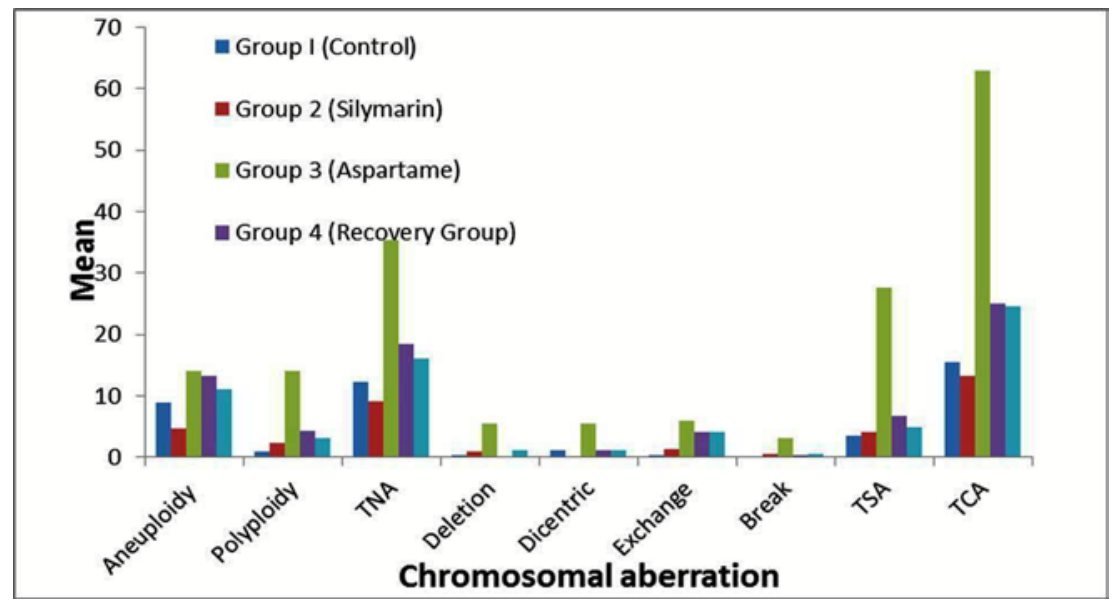

Fig. 9: Histogram of mean values of different types of chromosomal aberrations in bone marrow cells of male albino rats after ASP and/or silymarin administration

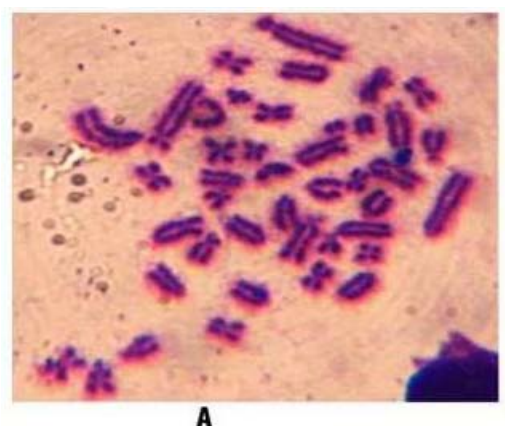

A

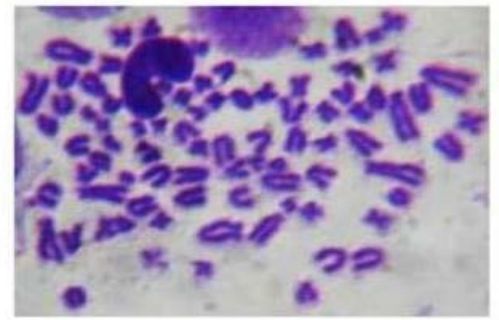

C

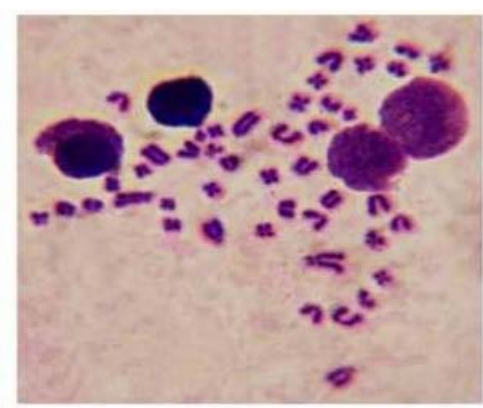

B

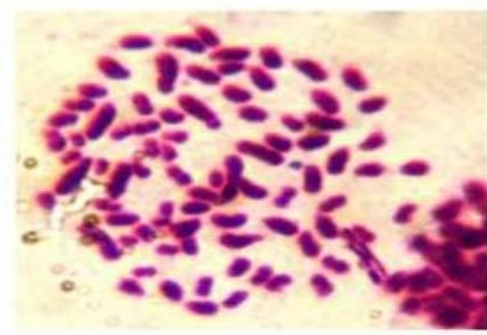

D

Fig. 10: Several metaphases from bone marrow cells of albino rat after ASP administration showed; Deletion (De), Dicentric (Di), Exchange fig. (Ex) and Break (Br) 


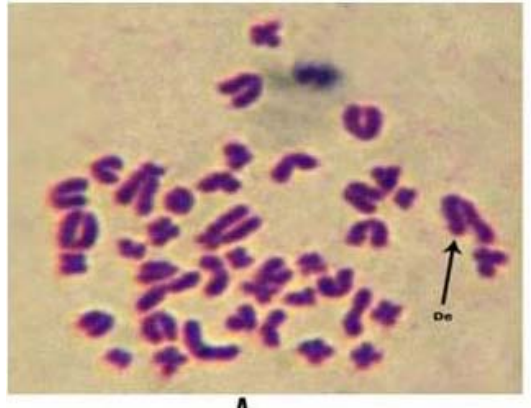

A

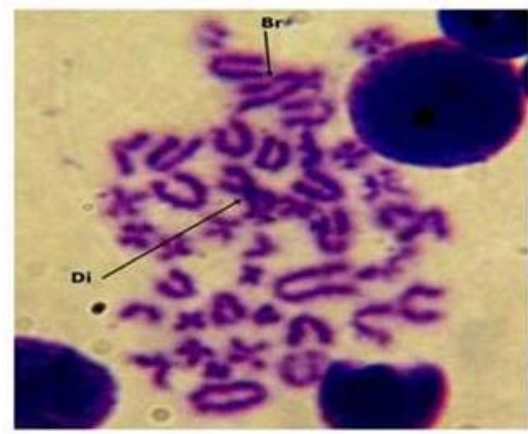

C
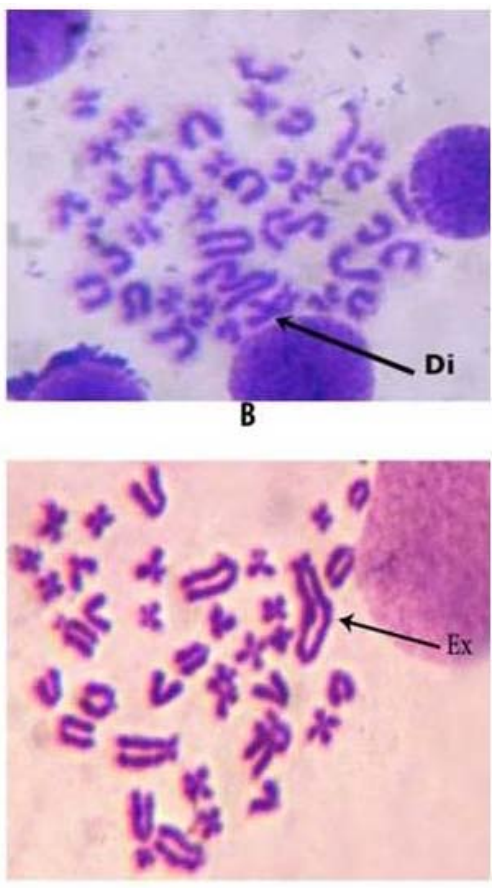

D

Fig. 11: Aberrant metaphases from bone marrow cells of albino rat after Asp administration showed: (A) Deletion (De); (B) Dicentric (Di); (C) Dicentric (Di) and Break (Br); (D) Exchange fig. (Ex)

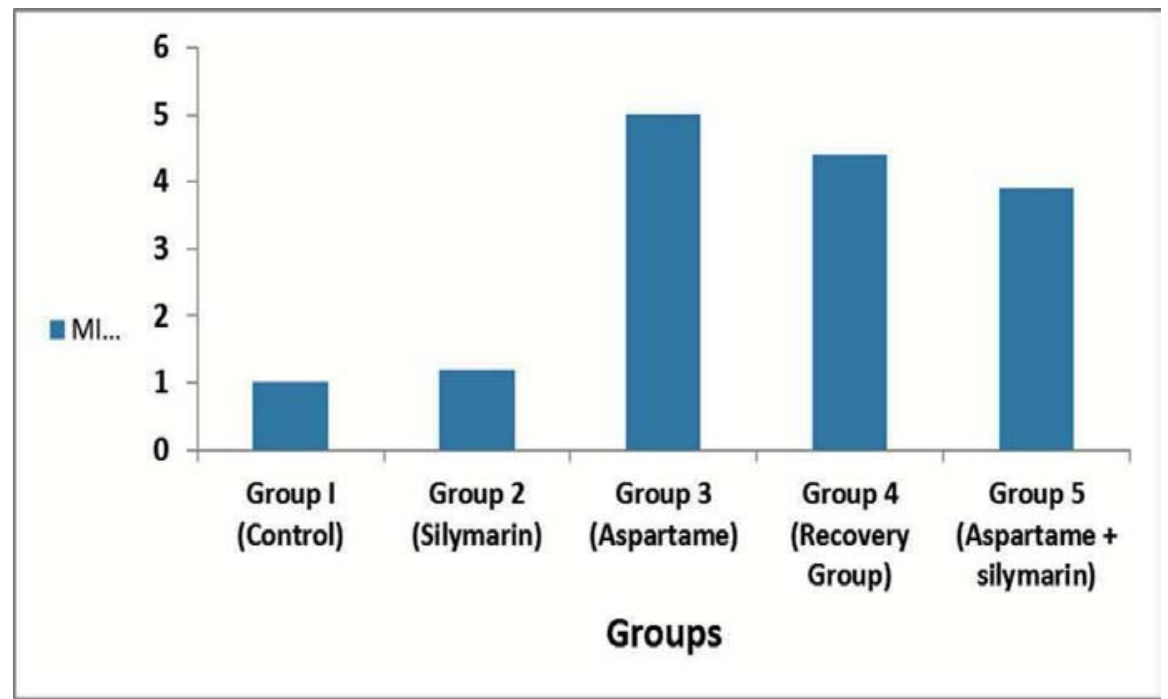

Fig. 12: Histogram showed MI\% of male albino rats after ASP and/or silymarin administration

\section{Histopathological examination on liver, kidney and heart tissue}

Findings of histopathological examination of liver tissue showed that the control group and Silymarin group showed a normal structure in the hepatic tissues which consisted of central vein and sheets of hepatocyte. Aspartame group showed diffuse hepatocytes vacuolations. Recovery group showed normal hepatic cords with the slightly congested hepatoportal blood vessel. Aspartame plus silymarin group showed mild picture of hepatocytes vacuolations (fig. 13).

According to the present study, the histopathological examination of kidney showed that the control group and silymarin group showed normal structure appearance of real tissue renal parenchyma, normal glomeruli and renal tubules. Aspartame group showed diffuse vacuolation of glomeruli, renal tubules together with congested interstitial blood vessel with the thickened wall. Recovery group showed normal renal parenchyma. Note the normal glomeruli and renal tubules. Aspartame plus silymarin group showed normal renal parenchyma. Note the normal glomeruli and renal tubules (fig. 14).

In the current study, the histopathological examination of cardiac tissue demonstrated that the control group and the silymarin group showed normal myocardial muscles. Aspartame group showed hyalinized myocardial muscle with dilated and thickened walled blood vessel. The recovery group showed normal myocardial muscle with a slightly dilated blood vessel. In Aspartame plus silymarin group, there were normal myocardial muscles (fig. 15). 


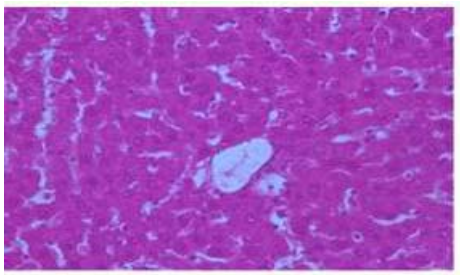

A1

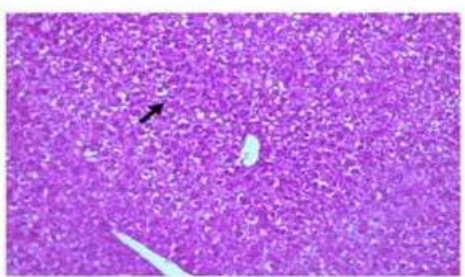

A3

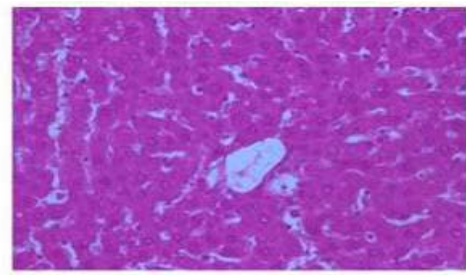

$\mathbf{A 2}$

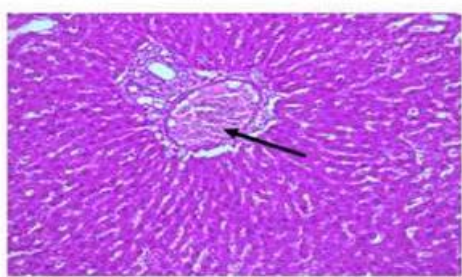

A4

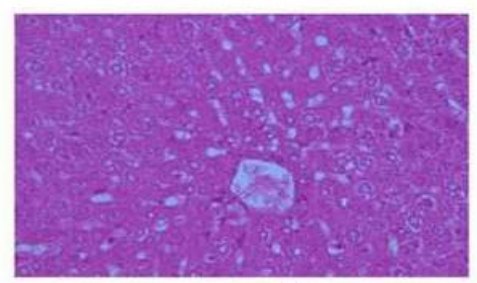

A5

Fig. 13: Histopathological examination of liver tissue. A1 and A2 refer to group 1 (normal control) and group 2 (Silymarin) showed normal structure all clearance of hepatic tissue which consists of central vein and sheets of the hepatocyte. A3 refer to group 3 (Aspartame) showed diffuse hepatocytes vacuolations (arrow). A4 refer to group 4 (Recovery) showed normal hepatic cords with slightly congested hepatoportal blood vessel (arrow). A5 (Aspartame+silymarin) showed mild picture of hepatocytes vacuolations, (HandE X 200 and 400)

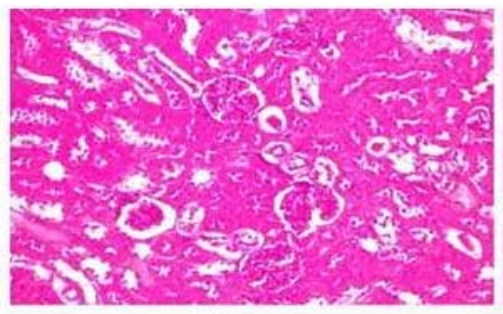

B1

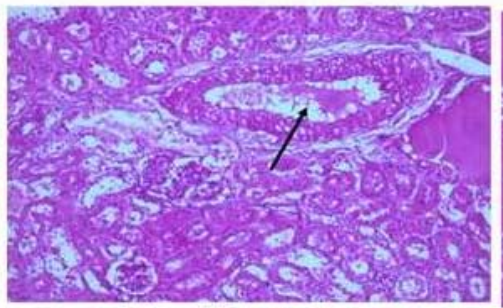

B3

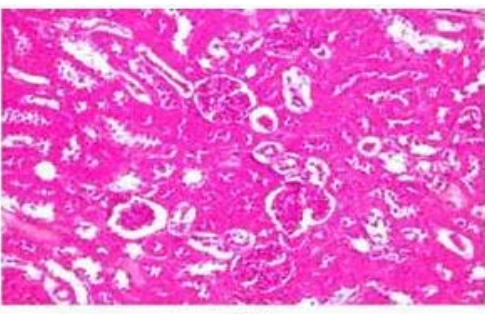

B2

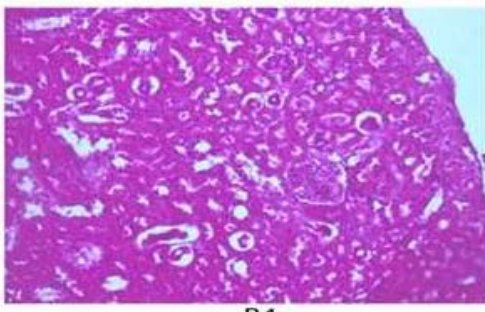

B4

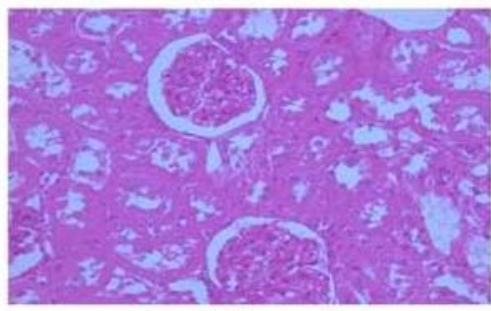

B5

Fig. 14: Histopathological examination of kidney tissue. B1 and B2 refer to group 1 (normal control) and group 2 (Silymarin) showed normal structure appearance of real tissue renal parenchyma, normal glomeruli and renal tubules. B3 refers to group 3 (Aspartame) showed diffuse vacuolation of glomeruli, renal tubules together with congested interstitial blood vessel with the thickened wall (arrow).

B4 refer to group 4 (Recovery) showed normal renal parenchyma, note the normal glomeruli and renal tubules. B5

(Aspartame+silymarin) showed normal renal parenchyma, note the normal glomeruli and renal tubules, (HandE X 200 and 400) 


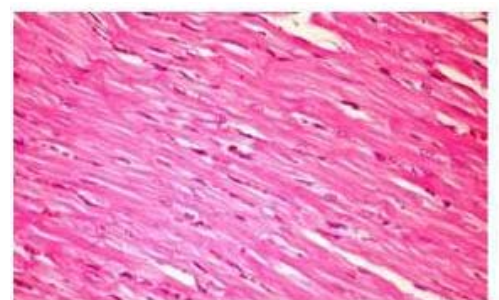

C1

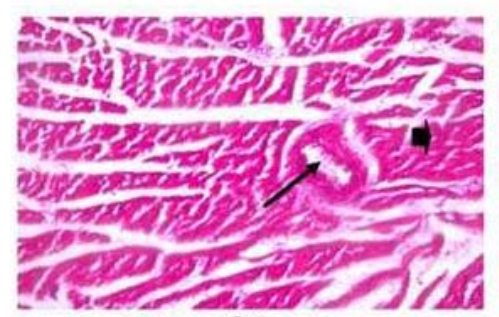

C3

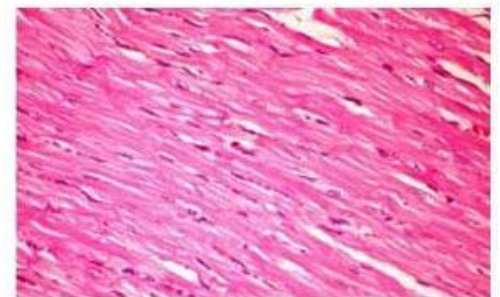

C2

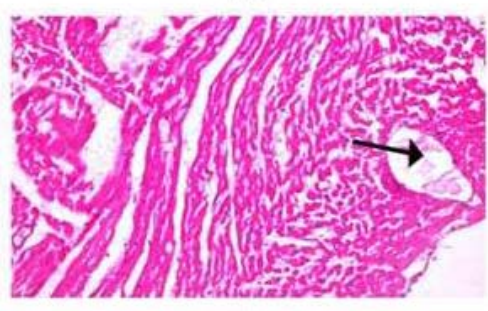

C4

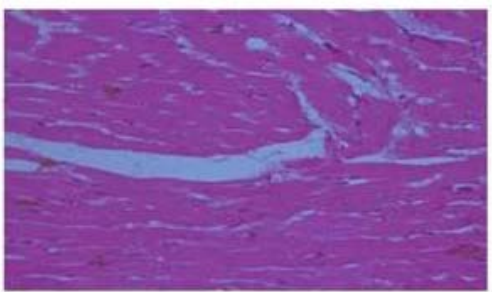

C5

Fig. 15: Histopathological examination of heart tissue. C1 and C2 refer to group 1 (normal control) and group 2 (Silymarin) showed normal myocardial muscles. C3 refer to group 3 (Aspartame) showed hyalinized myocardial muscle (arrowhead) with dilated and thickened walled blood vessel. C4 refer to group 4 (Recovery) showed normal myocardial muscle with a slightly dilated blood vessel (arrow). C5 (Aspartame+silymarin) showed normal myocardial muscles, (HandE X 200 and 400)

\section{DISCUSSION}

The synthetic and some of the naturally present food additives have been reviewed and documented for toxicity. Limit values have been evaluated for dietary intake by humans on the basis of the conclusion of data attained in experimental animals.

In the current investigation, we studied the ASP induced toxic effects and biochemical variations in blood and different tissues in addition to the CA frequencies and MI\% in experimental rats. The effect of coadministration of ASP and silymarin and the role of silymarin in the amelioration of these toxic effects were also examined.

\section{The effect on body weight}

Data showed that there was a significant increase in the final body weight in group 3 (aspartame) $(\mathrm{P}<0.001)$ and Group 4 (Recovery Group) $(\mathrm{P}<0.05)$ which amounted to $27.1 \%$ and $13.8 \%$ respectively. In group 5 (Aspartame+silymarin) there was a statistically nonsignificant increase in the final body weight which amounted to $7 \%$ (table 1) and (fig. 1).

These results are in line with who reported that rats, when treated with aspartame, had an increase in food and water intake. ASP increases appetite in rats. Appetite is known as a highly regulated phenomenon characterized by hunger and satiety as crucial factors in controlling food intake $[37,38]$.

Sweetness without energy has impacts on appetite because of a natural sweetness-energy association. Due to this association, it has been proposed that sweetness could be an indication of the arrival of the associated energy and its physiological and psychological effects on appetite [39].

In the case of the absence of the associated energy, as in the case of artificial sweeteners, the body needs energy, leading to the stimulation of appetite [40]. ASP increases appetite through its metabolites by different mechanisms. An increased phenylalanine concentration may encourage admission by means of the hypothalamic adrenoreceptors implicated in the central appetite control mechanisms, stimulating appetite [41]. The aspartate, which is the metabolite of aspartame, reached the brain in the arcuate (ARC) nucleus. This nucleus is the main place where the synthesis of neuropeptide Y (NPY), stimulates carbohydrate intake. Also, chronic ASP administration significantly decreased leptin concentration in plasma [42]. Leptin inhibits food intake in the brain, but lower concentrations of leptin, could stimulate appetite [43].

Increased fluid intake can be associated with the intensive sweet taste of ASP and its hedonic impact. ASP is about 200 times sweeter than sucrose [44].

Data had revealed that there was a significant increase in the final body weight in group 4 amounting $13.8 \%$. This indicated improvement when rats were recovered for $14 \mathrm{~d}$. These results are in accordance with who reported that improvement of the ASP produced changes but never returned to control ones in rats that received ASP and were then left for $4 \mathrm{w}$ to recover [45].

In group 5 , there was a statistically non-significant increase in the final body weight which amounted to $7 \%$. This indicates the role of silymarin in restoring the side effects of ASP.

\section{Effect on glucose, liver, kidney and lipid function tests}

Data presented in (table 2) and (fig. 2) showed that the mean level of glucose was increased in groups 3,4 and 5. This increase was statistically significant in group $3(\mathrm{P}<0.01)$ and group $4(\mathrm{P}<0.05)$. In group 5 silymarin administration decreased glucose level which was statistically non-significant compared to the control group $(P>0.05)$.

These results are in line with who reported that the control group demonstrated a glucose concentration underneath those of aspartame groups $(\mathrm{P}<0.05)$ [38]. Also, previous data declared that ASP consumption significantly increased blood glucose level $(\mathrm{P}<0.05)$, in a dose and time-dependent fashion [46]. 
Artificial sweeteners, including ASP, bring about impedance in insulin sensitivity [47]. Moreover, phenylalanine, resulting from ASP metabolism, may increase insulin and glucagon values in serum of healthy subjects [48]. It may induce an elevation of hepatic glucose production and its level in the blood of rats [49].

In group 4 , there was a statistically significant $(\mathrm{P}<0.05)$ increase in glucose level indicating an improvement but not returning to normal values. In group 5, silymarin administration decreased the elevation in glucose level which was statistically non-significant ( $P>0.05$ ) compared to the control group. These results were in agreement with who reported that there was an amelioration of blood glucose concentration in nickel animals treated with silymarin extract [50]. It was suggested that the protective role of silymarin was due to its antioxidant properties, an expansion of plasma and pancreatic glutathione concentrations or both [51].

Also, data showed a significant $(\mathrm{P}<0.05)$ increase in ALT activity in group 3. This value was decreased in group 4 and 5 ( $P>0.05)$. The mean value of AST activity increased in group 3, 4 and 5 but this increase was statistically non-significant $(\mathrm{P}>0.05)$ compared to the control group. ASP administration caused slight decrease in the mean level of albumin $(\mathrm{P}>0.05)$ and slight increase in total bilirubin $(\mathrm{P}>0.05$ ) (table 2) and (fig. 2).

Data supported who recorded that a highly significant increase in ALT, AST and ALP activity was recorded in Wistar albino rats treated with ASP compared to controls [52].

At this point, ASP was retained from the intestinal lumen and compasses to liver by means of entrance course likewise to other amino acids. [53] Methanol is a chemical compound that is harmful to liver cells. It is oxidized to formaldehyde resulting in formate production [53]. When liver cells are damaged, it releases variety of enzymes that normally found in cytoplasm into the bloodstream. Therefore, their levels in the serum are valuable as a demonstrative marker of the degree and kind of hepatic damage.

Previous studies indicated a critical diminishing of level of serum albumin in contrast with the untreated group. Oral dosing of ASP had no impact on total serum protein at $45 \mathrm{~d}$, but it essentially diminished at $90 \mathrm{~d}$ of administration [54].

Other studies revealed that administration of silymarin concomitantly with dexamethasone-induced a significant reduction of liver function enzymes (ALT, AST and ALP) and the significant increase in total protein and globulin as compared with dexamethasone-treated group alone [55]. This may be attributed to the protection of liver cells directly through stabilizing the cell membrane by preventing liver glutathione depletion and inhibiting lipid peroxidation, regulating cell membrane permeability and integrity inhibiting leukotriene and scavenging reactive oxygen species [56].

Data confirmed that ASP administration caused a slight increase in urea concentration ( $\mathrm{B}$ 0.05). ASP caused a significant $(\mathrm{P}<0.01)$ increase in the mean level of creatinine. These values showed a slight decrease in group 4 . But this was still statistically significant. Group 5 had marked decrease which was statistically non-significant $(P>0.05)$ as compared to control group (table 2) and (fig. 2, fig. 3).

These results were in line with who showed that oral administration of ASP produced a significant increase in the levels of serum urea, creatinine. The ASP induced damage of kidney function was proved by elevation serum creatinine and urea levels [57]. This meant the diminished ability of the kidney to eliminate the toxic metabolic [58].

Previous studies observed that the administration of silymarin with dexamethasone-induced marked decrease in urea and creatinine concentrations [55].

The present result declared that the dosing of ASP caused a significant increase in the mean level of Cholesterol $(P<0.01)$ and triglyceride in group $3(\mathrm{P}<0.001)$. These values showed slight decrease in group 4 . But this was still statistically significant. Group 5 had marked decrease which was statistically non-significant (P> 0.05 ) as compared to control group (table 2) and (fig. 2).
These outcomes agreed with who announced that the administration of ASP had a fundamentally expanded level of cholesterol and triglycerides in rats $[37,54]$.

Cholesterol is a major component of cell membranes. It is important for tissue growth and the production of steroid hormones. The regulation of cholesterol metabolism is regulated by the liver. ASP caused changes in different biochemical parameters, lipid metabolism and may be the cause of hyperglycemia and hypercholesterolemia [59].

Other authors have shown that hypersensitivity and atherosclerosis resulted from long-term ASP administration. Oxidative stress and oxidative damage of tissue could be the initial markers of some chronic diseases, like diabetes [60]. In diabetes, high glucose causes increased production of ROS in all tissues resulting from glucose auto-oxidation and protein glycosylation [61].

\section{The effect on oxidative and antioxidative parameters in liver} tissue

Data showed that the dosing of ASP caused a marked significant increase on hepatic MDA level $(\mathrm{P}<0.001)$ and a significant decrease on GSH levels $(\mathrm{P}<0.05)$, GST and catalase activities $(\mathrm{P}<0.001)$ as compared to the control group. The elevation on MDA level showed slight decrease in group $4(\mathrm{P}<0.01)$ and a marked decrease in group 5 but it remained significant $(\mathrm{P}<0.05)$ at the statistical level. Also, the decrease on hepatic GSH level, GST and catalase activities were enhanced in group 4 but, it was statistically significant as group 3 and showed marked elevation in group 5 which was statistically non-significant $(\mathrm{P}>0.05)$ as compared to the control group (table 3$)$.

Previous data concluded that ASP administration caused a significant decrease in the hepatic levels of antioxidant enzymes (SOD, CAT and GPx); maybe due to the destroying effect caused by methanol associated free radicals or formaldehyde obtained from methanol oxidation [62].

Free radicals, including superoxide radical, hydroxyl radical, hydrogen peroxide and lipid peroxide radicals, are delivered as an ordinary outcome of biochemical procedures in body cells and expanded introduction to lethal compounds [63]. Free radicals induce peroxidation of polyunsaturated fatty acid in the cell membrane. This causes a chain reaction of lipid peroxidation, harms the cellular membrane and causes further oxidation of membrane lipids and proteins, DNA, RNA and other components [64]. The protective role of silymarin on the cells is mainly due to its antioxidant activity. Overall, the protective role of silymarin on liver includes its activity against lipid peroxidation as a result of free radical scavenging and its capacity to build GSH content in addition to silymarin's ability to regulate the cell membrane permeability and to increase membrane stability in the presence of harmful agents damage [65].

\section{The Effect on oxidative and antioxidative parameters in kidney tissue}

Results confirmed that ASP administration caused a highly significant elevation in kidney MDA level $(\mathrm{P}<0.01)$ and a significant decrease in GSH levels $(\mathrm{P}<0.01)$, GST and catalase activities $(\mathrm{P}<0.001)$ as compared to the control group. The elevation in MDA level showed slight decrease in group $4(\mathrm{P}<0.01)$ and a marked decrease in group 5 but, it was still significant $(\mathrm{P}<0.05)$ at the statistical level. The decreased kidney GSH level, GST and catalase activities were enhanced in group 4, but the values were remained statistically significant as group 3 and showed marked elevation in group 5 which was statistically non-significant $(\mathrm{P}>0.05)$ in case of GSH and catalase and significant $(\mathrm{P}<0.05)$ in MDA and GST as compared to control group (table 4).

Results were in line with who revealed that oral administration of ASP to rats caused a significant increase in the levels of oxidative stress markers as compared to the control group. This indicated that ASP caused renal toxicity by oxidative stress due to the production of a number of free radicals by its metabolites (methanol) [57].

Other studies showed that GSH, GST, GPx and SOD activities were significantly diminished $(\mathrm{P}<0.01)$ in the kidney, while MDA level 
witnessed a highly significant expansion $(\mathrm{P}<0.01)$ in ASP treated rats as compared to controls.

The reduction in GSH action was brought about by methanol since methanol metabolism relied upon GSH. Maybe it was brought about by its quick interaction with formaldehyde, created during methanol metabolism and forming nucleophilic adducts and/or lipid peroxidation products [66]. The lessening in action of cancer prevention agent chemicals is connected with the activity formaldehyde and free radicals. Formaldehyde rapidly interacts with the amino acids of soluble proteins causing hydroxymethyl derivatives and intra and intermolecular bridges in proteins. Also, free radicals produced through the methanol oxidation can cause the formation of protein peroxides. These changes may result in denaturation, aggregation and fragmentation of proteins, changing physicochemical properties and potentially losing enzymatic activities [67].

\section{The effect on oxidative and antioxidative parameters in heart} tissues

The present study recorded that ASP administration caused a highly significant elevation in cardiac MDA level $(\mathrm{P}<0.001)$ and a significant decrease in GSH levels $(\mathrm{P}<0.01)$, GST and catalase activities $(\mathrm{P}<0.001)$ as compared to control values. The elevation in MDA level showed a slight decrease in group $4(\mathrm{P}<0.05)$ and a marked decrease in group 5 which was statistically non-significant $(\mathrm{P}>0.05)$. The decreased cardiac GSH level, GST and catalase activities were enhanced in group 4 but still statistically significant as group 3 and showed marked elevation in group 5 which was statistically nonsignificant $(\mathrm{P}>0.05)$ as compared to control group (table 5).

ASP administration for 3 mo to Wistar albino rats caused a significant decrease in enzymatic (SOD, CAT and GPX) and nonenzymatic (GSH, Vit-C and Vit-E) antioxidants level when compared to the control animals [68].

Data showed that ASP has an effect on the different tissues. Recovery period (14 d) was not enough to restore the oxidative and antioxidative parameters to its normal levels. Also, co-administration of ASP with silymarin showed great improvement than the recovery group (fig.4, fig. 5, fig. 6, fig. 7).

\section{The effect on serum levels of TNF-- $\alpha$}

Tumor necrosis factor- $\alpha$ (TNF- $\alpha$ ) is a pro-inflammatory cytokine produced in blood. It initiates the immune response. TNF- $\alpha$ is secreted by different types of cells. It is produced by activated macrophages, endothelial cells and B lymphocytes. It induced apoptosis, increased blood coagulation, increased expression of adhesion molecules on WBCs and endothelial cells, as well as the release of different cytokines, chemokines, leukotrienes and ROS [67]. These ROS are known to regulate different important cellular events in response to TNF- $\alpha$, including NF-kB, cellular proliferation, and apoptosis [69].

Results presented in (table 6) indicated that there was a highly significant increase in the mean level of serum TNF- $\alpha$ in group 3 $(\mathrm{P}<0.001)$ as compared to control group. Group 4 showed a significant increase $(\mathrm{P}<0.05)$ but less than that of group 3 . In group 5 , there was statistically non-significant increase.

The high level of TNF- $\alpha$ is generally found in persons with metabolic disorder diseases like obesity and diabetes. It was reported that ASP acted as a chemical stressor and increased oxidative stress leading to inflammation [70]. TNF- $\alpha$ was observed to straight-forwardly interfere with tissue insulin receptors and leads to blocking insulin's biological actions on cell. This causes insulin resistance because of TNF- $\alpha$ exposure [71].

These findings were in line with who confirmed that ASP increased serum TNF- $\alpha$ in mice as compared to controls [72]. Silymarin was able to restrict the excessive inflammation caused by stress by acting on a variety of molecular targets. It inhibited the production of TNF$\alpha$ in a dose-dependent manner in rats [73].

\section{The effect on the chromosomal aberration frequency}

Under the conditions of the present investigation, the control rats recorded chromosomal aberration (CA) frequency within the normal values while oral administration of ASP to male rats induced significant $(\mathrm{p}<0.001)$ increase in the percentage of total chromosomal aberration (TCA) reaching $63.00 \pm 2.89$ as compared with $15.60 \pm 0.67$ in control group. TCA included the total numerical aberration (TNA) and the total structural aberration TSA (table 7) (fig. 9).

The numerical aberrations were mainly the aneuploidy (hyperdiploid) and polyploidy (table 7), (fig. 9, fig. 10). Meanwhile, the deletions, dicentric chromosomes, exchange fig. and breaks were the most abundant structural aberrations (table 7), (fig. 9, fig. 11); all of these aberrations significantly $(\mathrm{p}<0.001)$ increased as compared with control values.

These results supported other previous studies who confirmed that ASP induced a significant increase in the TCA (structural and numerical) in liver and bone marrow cells of albino rat's mothers and their offspring [13], in Swiss albino mice [74, 75] and in human lymphocytes as compared with control values. Chromosome breaks, Chromatid breaks, single chromatid union and sister union were the most common CA [76].

On the contrary, the present results disagreed with who recorded that ASP had a moderate genotoxic effect [77]. Also, ASP and acesulfame-K administration induced no significant increase in the frequency of CA in Swiss albino mice bone marrow cells [78].

Genotoxicity of ASP in bone marrow cells of rats might be caused mainly by the toxic methanol (a metabolite of ASP) where ASP can be hydrolyzed into phenylalanine, aspartic acid, a cyclized diketopiperazine and methanol. Methanol further hydrolyzed to formaldehyde, which is concluded to be one of the DNA damaging agents and known to induce CA in living cells [79]. Also, ASP could induce DNA fragmentation and CA by increasing methanol levels in plasma which, in turn, induced a significant increase in the free radical production causing an imbalance in the ratio of antioxidant/pro-oxidant in the brain tissue in male waster rats [67, 80, 81]. Methanol and phenylalanine are the metabolic components of ASP having a genotoxic effect for humans [76].

In the present study, when rats were orally administered with ASP then left for two weeks post-treatment to recover (recovery group), the frequency of TCA (TNA and TSA) was clearly reduced as compared with ASP group. Hyperdiploid and polyploidy were decreased but their values remained significant $(p<0.01)$ as compared with control (table 7) and (fig. 9). Except for exchange figures, all types of structural aberrations decreased and became non-significant at the statistical level. Thus, better CA improvement after the stoppage of ASP may require an extension of the recovery period to more than two weeks.

This result completely agreed with [82] who confirmed that the administration of ASP had harmful effects on the sciatic nerve and one-month discontinuation of ASP was not enough to obtain complete recovery.

It is known that anti-oxidizing agents are confirmed to be useful in preventing or treating damage induced by free radicals. So, silymarin was used in the present investigation to ascertain whether the coadministration of ASP and silymarin is effective in reducing genotoxicity induced by ASP in bone marrow of albino rats.

According to the result of the present study, silymarin treated rats showed significant $(\mathrm{p}<0.05)$ decrease in the frequency of TNA as compared with control value. Herein, aneuploidy (hyperdploid) was significantly $(\mathrm{p}<0.05)$ decreased and all other types of CA were nonsignificantly changed. This confirmed that silymarin itself does not induce CA and is able to repair the chromosomal damage (table 7) and (fig. 9).

These results completely confirmed who explained that silymarin is highly safe; there are no lethal doses recorded for humans or animals. It didn't induce chromosomal aberrations in germ and somatic cells in albino mice [83].

Moreover, the present data revealed that the silymarin drug as antioxidant alleviated the genotoxicity of ASP by clear reduction in 
the frequency of TCA (TNA and TSA) in bone marrow cells of rats coadministered both ASP plus silymarin. All types of CA (hyperdiplod, polydiploidy, deletions, dicentic chromosomes and breaks) were highly reduced and became non-significant as compared with control values. However, the frequency of TCA (TNA and TSA mainly exchange figures) remained significant as compared with control values (table 7) and (fig. 9). The ameliorative role of silymarin against ASP toxicity might be a result of its anti-oxidative activity; it acts as a scavenging agent against the free-radicals induced by ASP that were the main cause of ASP genotoxicity repairing the chromosomal damage in bone marrow cells of ASP treated rats.

These results were confirmed by who recorded that the combined treatment with silymarin and cyclophosphamide revealed that the silymarin successfully decreased frequency of all types of CA in mice[84]. Silymarin is a powerful antioxidant agent; it increases the activity of both glutathione peroxidase and superoxide dismutase promoting the free radical scavenging activity of glutathione of glutathione peroxidase system $[85,86]$.

\section{The effect on the percentage of the mitotic index}

According to the present work, the percentage of MI was increased in ASP group as compared with control value (table 7) and (fig. 12). Increased MI rate might result from a high progression rate of cells from the stage of DNA synthesis (S-phase) to mitosis (M-phase) of the cell cycle. This indicates the potential of ASP to induce more cells to divide and hence inducing cancer cells.

Results fully agreed with who recorded that ASP induced a significant increase in the percentage of MI in Allium cepa L. meristematic cells compared with control group [87]. MI is significant for measuring the cell division rate [88].

In contrast, it was reported that ASP decreased the MI at all treatment periods and all concentrations in dose-dependent manner $[74,76]$. Also, ASP did not significantly affect MI\% [75]; many in vivo and in vitro studies showed that ASP is not genotoxic agent [89].

The present data recorded that the value of MI was relatively decreased in the recovery group as compared with the aspartame group (table 7) and (fig. 12). Rats had been left for $14 \mathrm{~d}$ posttreatment with ASP to recover and this period was not enough to reach a complete recovery.

This confirmed the data concluded by who reported that the improvement from ASP induced cytotoxic effect was gradual and incomplete [19].

In addition, data showed that there was no significant change in MI\% in silymarin treated rats. The animals administered with both ASP plus silymarin recorded an improvement in MI\% as compared with rats treated with ASP alone, but the value didn't reach the control level (table 7) and (fig. 12).

These data supported who recorded that silymarin is famous as a safe herbal product [90]. It has a powerful anticlastogenic activity on genome of mice in germ and somatic cells. It has the ability to reduce the induction of sister chromatid exchange, giving a confirmation that it plays a remarkable role in repairing DNA damage. This role may be due to the action of silymarin as a strong antioxidant, or a DNA stabilizing agent. Thus, the usage of silymarin for the treatment of many diseases is not only safe but also has an anti-mutagenic activity warranted [91].

\section{Histopathological examination}

Findings of histopathological examination of liver tissue showed that the control group and Silymarin group showed a normal structure in the hepatic tissues which consisted of central vein and sheets of hepatocyte. Aspartame group showed diffuse hepatocytes vacuolations. Recovery group showed normal hepatic cords with slightly congested hepatoportal blood vessel. Aspartame plus silymarin group showed mild picture of hepatocytes vacuolations (fig. 13).

These results were in line with [52] who recorded critical changes in the livers of ASP treated animals when compared to control.
Significant amount of neutrophil infiltration was noticed in the liver cells. ASP treatment caused necrosis in liver histopathology with the spillage of blood cells. There were clear toxicological consequences for the hepatic tissue; significantly obtained in female rats treated with a dose of aspartame of $500 \mathrm{mg} \mathrm{kg}-1$ daily in drinking water [92].

According to the present study, histopathological examination of kidney showed that control group and silymarin group showed normal structure appearance of real tissue renal parenchyma, normal glomeruli and renal tubules. Aspartame group showed diffuse vacuolation of glomeruli, renal tubules together with congested interstitial blood vessel with thickened wall. Recovery group showed normal renal parenchyma. Note the normal glomeruli and renal tubules. Aspartame plussilymarin group showed normal renal parenchyma. Note the normal glomeruli and renal tubules (fig. 14).

These observations agreed with who viewed that the histopathological profile of the rat kidney treated with ASP showed congestion in the sclerotic cortical blood vessels with swelling in the coating epithelial cells of the tubules [93].

In the current study, the histopathological examination of cardiac tissue demonstrated that control group and silymarin group showed normal myocardial muscles. Aspartame group showed hyalinized myocardial muscle with dilated and thickened walled blood vessel. Recovery group showed normal myocardial muscle with slightly dilated blood vessel. In Aspartame plus silymarin group there were normal myocardial muscles (fig. 15). Results disagreed with who reported that there was no morphological difference in heart of ASP treated Wistar albino rats when compared to control [68]

\section{CONCLUSION}

The results of the current study have proved that ASP has cytotoxic effect that mayevidenced by inducing a significant increase in the liver, kidney and lipid function tests, blood glucose level, serum TNF$\alpha$ level, MDA level, CA frequency and MI\%. This is in addition to decreasing GSH level, GST and catalase activity. Recovery period (14 d) after ASP stoppage was not enough to restore the oxidative and anti-oxidative parameters to normal levels. Silymarin, as an antioxidant, has the ability to ameliorate ASP toxicities. Therefore, it is important to be very careful when adding ASP in beverages and foods as a sweetener. It must be added together with antioxidants like silymarin.

\section{ABBREVIATION}

Total numerical aberrations, TNA; Total structural aberrations, TSA; Total chromosomal aberrations, TCA.

\section{FUNDING}

Nil

\section{AUTHORS CONTRIBUTIONS}

All the authors have contributed equally.

\section{CONFLICT OF INTERESTS}

Declared none

\section{REFERENCES}

1. Sahelian R. Aspartame sweetener side effects, safety, risk and dan-ger. Natural alternatives to this artificial sweetener; 2014.

2. Humphries P, Pretorius E, Naude H. Direct and indirect cellular effects of aspartame on the brain. Eur J Clin Nutr 2008;62:451e62.

3. Stegink LD. Aspartate and glutamate metabolism. In: Stegink LD, Filer Jr LJ. editors. Aspartame physiology and biochemistry. New York: Marcel Dekker; 1984. p. 47e-76.

4. Harper AE, Stegink LD, Filer LJJ. Phenylalanine metabolism. Newyork: Marcel Dekker; 1984. p. 77e109.

5. Opperman JA, Stegink LD, Filer LJ. Aspartame metabolism in animals. New York: Marcel Dekker; 1984. p. 141e59.

6. Butchko H. Aspartame review of safety. Regul Toxicol Pharmacol 2002;35:S1e93. 
7. Soffritti M, Belpoggi F, Manservigi M, Tibaldi E, Lauriola M, Falcioni L. Aspartame administered in feed, beginning prenatally through life span, induces cancers of the liver and lung in male swiss mice. Am J Ind Med 2010;53:1197-206.

8. Fagherazzi G, Vilier A, SaesSartorelli D, Lajous M, Balkau B, Clavel Chapelon F. Consumption of artificially and sugarsweetened beverages and incident type 2 diabetes. Am J Clin Nutr 2013;97:517-23.

9. Englund Ogge L, Brantsæter AL, Haugen M, Sengpiel V, Khatibi A, Myhre R, et al. Association between intake of artificially sweetened and sugar-sweetened beverages and preterm delivery: a large prospective cohort study. Am J Clin Nutr 2012;96:552-9.

10. Saleh AAS. Synergistic effect of N-acetyl cysteine and folic acid against aspartame-induced nephrotoxicity in rats. Int J Adv Res 2014;2:363-73.

11. El Haliem NGA, Mohamed DS. The effect of aspartame on the histological structure of the liver and renal cortex of adult male albinorat and the possible protective effect of pimpinellaanisum oil. Egypt J Histol 2011;34:715-26.

12. El Sakhawy M, Saeid S. Effect of long term administration of aspar-tame on the parotid salivary glands of male albino rats. Int J Adv Res 2014;2:850-85.

13. AbdElfatah AAM, Ghaly IS, Hanafy SM. Cytotoxic effect of aspartame (diet sweet) on the histological and genetic structures of female albino rats and their offspring. Pak J Biol Sci 2012;15:904-18.

14. Kren V, Walterova D. Silybin and silymarin-new effects and applications. Biomed 2005;149:29-41.

15. Kroll DJ, Shaw HS, Oberlies NH. Milk thistle nomenclature: why it mattersin cancer research and pharmacokinetic studies. Integr Cancer Ther 2007;6:110-9.

16. Hassani FV, Rezaee R, Sazegara H, Hashemzaei M, Shirani K. Effects of silymarin on neuropathic pain and formalin-induced nociception inmice. Iran J Basic Med Sci 2015;18:715-20.

17. WenWu J, Lin L, Tsai T. Drug-drug interactions of silymarin on the perspective of pharmacokinetics. J Ethnopharmacol 2009;121:185-93.

18. Fraschini F, Demartini G, Esposti D. Pharmacology of silymarin. Clin Drug Invest 2002;22:1.

19. Christian B, McConnaughey K, Bethea E, Brantley S, Coffey A. Chronic aspartame affects T-maze performance, brain cholinergic receptors and $\mathrm{Na}+, \mathrm{K}+-\mathrm{ATPase}$ in rats. Pharmacol Biochem Behav 2004;78:121-7.

20. Hjelle JJ, Dudley RE, Marietta MP, Sanders PG, Dickie BC. Plasma concentrations and pharmacokinetics of phenyl-alanine in rats and mice administered aspartame. Pharmacology 1992;44:4860.

21. Thavasu PW, Longhurst S, Joel SP, Slevin ML, Balkwill FR. Measuring cytokine levels in blood. Importance of anticoagulants, processing and storage conditions. J Immunol Methods 1992;153:115-24.

22. Nasri H, Mortazavi M, Ghorbani A, Shahbazian H, Kheiri S. Oxford MEST classification in IgA nephropathy patients: a report from Iran. J Nephropathol 2012;1:31 42

23. Trinder P. Determination of glucose in blood using glucose oxidase with an alternative oxygen receptor. Ann Clin Biochem 1969;6:24-7.

24. Patton C, Crouch R. Spectrophotometric and kinetics investigation of the berthelot reaction for the determination of ammonia. Anal Chem 1977;49:464-9.

25. Bartels H, Böhmer M, Heierli C. Serum creatinine determination without protein precipitation. Clin Chim Acta 1972;37:193-7.

26. Malloy HT, Evelyn KA. The determination of bilirubin with the photometric colorimeter. J Biol Chem 1937;119:481-90.

27. King J. The transaminases: alanine and aspartate transaminases. 15. In: Van D, editor. Practical clinical enzymology. London: Van D. Nostrand Co; 1965. p. 363-95.

28. King J. The hydrolases-acid and alkaline phosphatases. In: 16 Van D. editor. Practical clinical enzymology. London: Van D. Nostrand Co; 1965. p. 199-208.

29. Van Handel E, Zilversmit DB. Micro-method for direct 12. Determination of serum triglycerides. J Lab Clin Med 1957;50:152-7.
30. Allain CC, Poon LS, Chan CSG. Enzymatic determination of total serum cholesterol. Clin Chem 1974;20:470-5.

31. Ohkawa H, Ohishi W, Yagi K. Assay for lipid peroxides in animal tissues by thiobarbituric acid reaction. Anal Biochemical 1979;95:351-8.

32. Beutler E, Duron 0, Kelly MB. Improved method for the determination of blood glutathione. J Lab Clin Med 1963;61:882-90.

33. Habig WH, MJbst MJ, Jakoby WB. Glutathione S-transferases: the first enzymatic step in mercapturic acid formation. J Biol Chem 1974;249:7130-9.

34. Aebi H. [13] Catalase in vitro. Methodes Enzymol 1984;105:121-6.

35. Preston RJ, Dean BH, Galloway BJ, Holden S, McFee AF, Shelby M. Mammalian in vivo cytogenetic assays. Analysis of chromosome aberrations in bone marrow cells. Mutat Res 1987;189:157-65.

36. Levesque R. SPSS programming and data management: guide for SPSS and SAS. Users. 4th ed. SPSS Inc. Chicago. IL; 2007. p. 60606-6412.

37. Prokic MD, Paunovic MG, Matic MM, Djordjevic NZ, Ognjanovic MI. Effects of aspartame on biochemical and oxidative stress parameters in rat blood. Arch Biol Sci 2015;67:535-45

38. Hassan MI. Low intake of aspartame induced weight gain and damage of brain and liver cells in weanling syrian hamsters. J Food Nutr Res 2016;4:152-6.

39. Appleton KM, Blundell JE. Habitual high and low consumers of artificially-sweetened beverages. Effects of sweet taste and energy on short-term appetite. Physiol Behav 2007;92:479-86.

40. Swithers SE, Davidson TL. A role for sweet taste. Calorie predictive relations in energy regulation by rats. Behav Neurosci 2008;122:61-173.

41. Leibowitz SF. Neurochemical systems of the hypothalamuscontrol of feeding and drinking behaviour and waterelectrolyte excretion. In: Handbook of the Hypothalamus. Eds. PJ Morgane, J Panksepp; 1980. p. 299-343.

42. Beck B, Burlet A, Max JP, Stricker Krongrad A. Effects of longterm ingestion of aspartame on hypothalamic neuropeptide $Y$, plasma leptin and body weight gain and composition. Physiol Behav 2001;75:41-7.

43. Caro JF, Sinha MK, Kolaczynski JW, Zhang PL, Considine RV. Leptin the tale of an obesity gene. Diabetes 1996;45:1455-62.

44. Humphries P, Pretorius E, Naud EH. Direct and indirect cellular effects of aspartame on the brain. Eur J Clin Nutr 2008;62:451-62.

45. Omar SMM. Effect of aspartame on the frontal cortex of adult male albino rats. a light and electron microscopic study. Egypt J Histol 2009;32:346-57.

46. Azeez 0, Alkass S. Effect of long-term consumption of aspartame on body weight, blood glucose, lipid profile, kidney and liver functions in rats. Int J Curr Adv Res 2018;7:14464-74.

47. Ferland A, Brassard P, Poirier P. Is aspartame really safer in reducing the risk of hypoglycemia during exercise in patients with type 2 diabetes? Diabetes Care 2007;30:e59.

48. Nuttall FQ, Schweim KJ, Gannon MC. Effect of orally administered phenylalanine with and without glucose on insulin, glucagon and glucose concentrations. Horm Metab Res 2006;38:518-23.

49. Finamor IA, Ourique GM, Pes TS, Saccol EMH, Bressan CA. The protective effect of $\mathrm{N}$-acetylcysteine on oxidative stress in the brain caused by the long-term intake of aspartame by rats. Neurochem Res 2014;39:1681-90.

50. Bouhalit S, Kechrid Z. Protective effect of silymarin extracted from silybummarianum seeds upon nickel-induced hepatotoxicity in albino wistar rats. Ann Microbiol Immunol 2018;1:1-5.

51. Cheng J, Xiao L. The application of silymarin to hepatitis fibrosis. Int J Diges Dis 2007;27:69-71.

52. Iyaswamy A, Wankhar D, Loganathan S, Shanmugam S, Rajan R. Disruption of redox homeostasis in liver function and activation of apoptosis on consumption of aspartame in folatedeficient rat model. J Nutr Intermediary Metabol 2017;8:41-50.

53. Trocho C, Pardo R, Rafecas I, Virgili J, Remesar X. Formaldehyde derived from dietary aspartame binds to tissue components in vivo. Life Sci 1998;63:337-49. 
54. Gafar HB, Taha N, Noeman SN, Mandour A, Lepda M. Protective role of alpha-lipoic acid against the deleterious effects of both natural and artificial sweetener (Sucrose and Aspartame) in albino rats. Alex J Vet Sci 2016;49:105-15.

55. El-Sawy AF, El-Maddawy ZKH, Ashoura NR. Role of silymarin in restoring the deleterious effects induced by dexamethasone in male rats. AJVS 2018;59:125-35.

56. Shelbaya LA. Evaluation of the protective and antioxidant activity of milkthistle on paracetamol-induced toxicity in rats. J Am Sci 2013;9:272-8.

57. Waggas A, Soliman K, Moubarz G, Abd Elfatah A, Taha M. Potential protective effects of aqueous extract of majoram leaves, against aspartame induced renal toxicity in female rats. American-Eurasian J Toxicol Sci 2015;7:267-78.

58. Bahr I, Zaki M. Renal genomic instability induced by aspartame and the possible influence of the flaxseed oil and coenzyme Q10 in male rats. Life Sci J 2014;11:301-8.

59. Kim JZ, Seo J, KH Cho. Aspartame-fed zebrafish exhibit acute deaths with swimming defects and saccharin-fed zebrafish have elevation of cholesteryl ester transfer protein activity in hypercholesterolemia. Food Chem Toxicol 2011;49:2899-905.

60. Jang W, Jeoung NH, Cho KH. Modified apolipoprotein (apo) Aby artificial sweetener causes severe premature cellular senescence and atherosclerosis with impairment of functional and structural properties of apoA-I in the lipid-free and lipidbound state. Mol Cells 2011;31:461-70.

61. Chaitanya KV, Pathan AAK, Mazumdar SS, Chakravarthi GP, Parine N. Role of oxidative stress in human health. J Pharm Res 2010;3:1330-3.

62. Prabhakar R, Vreven T, Morokuma K, dMusaev DG. Elucidation of the mechanism of selenoprotein glutathione peroxidase (GPx) catalyzed hydrogen peroxide reduction by two glutathione molecules: a density functional study. Biochemistry 2005;44:11864-71.

63. Miguez MP, Anundi I, Sainz Pardo LA, Lindros KO. Hepatoprotective mechanism of silymarin: no evidence for involvement of cytochrome P4502E1. Chem Biol Interact 1994;91:51-63.

64. Miller AL. Antioxidant flavonoids: structure, function and clinical usage. Altern Med Rev 1996;1:103-11.

65. Kshirsagar A, Ingawale D, Ashok P, Vyawahare N. Silymarin: a comprehensive review. Pharmacogn Rev 2009;3:116-24.

66. Iman, Mourad M. Effect of aspartame on some oxidative stress parameters in liver and kidney of rats. Afr J Pharm Pharmaco 2011;5:678-82.

67. Abhilash MMV, Paul S, Varghese MV, Nair RH. Effect of long term intake of aspartame on antioxidant defense status in liver. Food Chem Toxicol 2011;49:1203-7.

68. Choudhary AK, Sundareswaran L, Devi RS. Aspartame induced cardiac oxidative stress in wistar albino rats. Nutr Clin Metabo 2016;30:29-37.

69. Kempf K, Rose B, Herder C, Haastert B, Fusbahn Laufenburg A Reifferscheid A, et al. The metabolic syndrome sensitizes leukocytes for glucose-induced immune gene expression. J Mol Med 2007;85:389-96.

70. Choudhary AK, Devi RS. Longer period of oral administration of aspartame on cytokine response in wistar albino rats Endocrinol Y Nutr 2015;62:114-22.

71. Hotamisligil GS, Spiegelman BM. Tumor necrosis $\alpha$ : a key component of the obesity-diabetes link. Diabetes 1994;43:1271-8.

72. Gul SS, Hamilton AR, Munoz AR, Phupitakphol T, Liu W, et al. Inhibition of the gut enzyme intestinal alkaline phosphatase may explain how aspartame promotes glucose intolerance and obesity in mice. Appl Physiol Nutr Metab 2017;42:77-83.
73. Jin YW, Zhao X, Zhang H, Li QS, Lu GD. Modulatory effect of silymarin on pulmonary vascular dysfunction through HIF-1 alpha-iNOS following rat lung ischemia-reperfusion injury. Exp Ther Med 2016;12:1135-40.

74. Kamath S, Vijaynarayana K, Shetty DP, Shetty P. Evaluation of genotoxic potential of aspartame. Pharmacologyonline 2010;1:753e769.

75. Al Suhaibani ES. In vivo cytogenetic studies on aspartame. Comparative and Functional Genomics; 2010. p. 1-4.

76. Rencuzogulları E, Berrin AT, Mehmet T, Hasan BI, Ahmet K Genotoxicity of aspartame. J Drug Chem Toxicol 2004;27:257-68.

77. Y Ilmaz S, Uçar A. A review of the genotoxic and carcinogenic effects of aspartame: does it safe or not? Cytotechnology 2014;66:875-81

78. Jeffrey AM, Williams GM. Lack of DNA-damaging activity of five non-nutritive sweeteners in the rat hepatocyte/DNA repair assay. Food Chem Toxicol 2000;38:335-8.

79. Rycerz K, Jaworska Adamu JE. Effects of aspartame metabolites on astrocytes and neurons. Folia Neuropathol 2013;51:10-7.

80. Abhilash M, Sauganth PMV, Mathews V, Varghese RHN. Longterm consumption of aspartame and brain antioxidant defense status. Drug Chem Toxicol 2013;36:135-40.

81. Prokic MD, Paunovic MG, Matic MM, Djordjevic NZ, Ognjanovic BI. Prooxidative effects of aspartame on antioxidant defense status in erythrocytes of rats. J Biosci 2014;39:859-66.

82. Ebtsam FO. Effect of long term administration of aspartame on the ultrastructure of sciatic nerve. J Microsc Ultrastruct 2016;4:175-83

83. Zhao J, Yogesh S, Rajesh A. Significant inhibition by the flavonoid antioxidant silymarin against 12-0-tetradecanoylphorbol 13-acetate-caused modulation of antioxidant and inflammatory enzymes, and cyclooxygenase 2 and interleukin- $1 \alpha$ expression in SENCAR mouse epidermis: Implications in the prevention of stage I tumor promotion. Mol Carcinog 1999;26:321-33.

84. Khatab AME. The drug silymarin has anticlastogenic activity. Alexandria Sci Exch J 2016;37:691-7.

85. Khatab AME. The anti-clastogenic activity of roselle (Hibiscus sabdariffa) extract using a variety of short-term genotoxic bioassays. EJ Genet Cyto 2014;43:425-40.

86. Lee Ji, Narayan M, Barrett JS. Analysis and comparison of active contituents in commercial standardized silymarin extract by liquid chromatography-electrospray. J Chromatocr B Anal Tech Biomed Life Sci 2007;1:845.

87. Rehab M, Rizk M, Soliman I, Aya AR. Potential mutagenicity of some artificial sweeteners using allium test. Asian J Adv Basic Sci 2016;4:27-40.

88. Moore PD, Patlolla AK, Tchounwou PB. Cytogenetic evaluation of malathion-induced toxicity in sprague-dawley rats. Mutat Res 2011;725:78-82.

89. Magnuson BA, Burdock GA, Doull J, Kroes RM, Marsh GM. Aspartame: a safety evaluation based on current use levels, regulations, and toxicological and epidemiological studies. Crit Rev Toxicol 2007;37:629-727.

90. Posadzki P, Watson LK, Ernst E. Adverse effects of herbal medicines: an overview of systematic reviews. Clin Med (Lond) 2013;13:7-12.

91. Anwar S, Hafez RM, Nafees A, Mohamed EW. In vivo anticlastogenic effect of silymarin from milk thistle Silybummarianum L. Indian J Pharmacol 2018;50:108-15.

92. Othman SI, Bin-Jumah M. Histopathological effect of aspartame on liver and kidney of mice. Int J Pharmacol 2019;15:336-42.

93. Hozayen WG, Soliman HE, Desouky EM. Potential protective effects of rosemary extract against aspartame toxicity in male rats. J Int Acad Res For Multidisciplinary 2014;2:111-25. 